\title{
SURVEY OF CRYOGENIC PROCESSES, PERIGLACIAL FORMS AND PERMAFROST CONDITIONS IN SOUTH AMERICA
}

Dario TROMBOTTO

\section{RESUMO}

Este inventário fornece informações sobre o estado da arte e os avanços recentes da Geocriologia nos países da América do Sul onde ocorre permafrost ou congelamento sazonal dos solos e onde este campo de pesquisa tem interesse científico. O objetivo é aumentar o conhecimento das atuais áreas geocriogênicas sob impacto de influências antrópicas e/ou de modificações climáticas. Uma breve análise climática ajuda a compreender as principais regiões criogênicas sul-americanas, ainda pouco conhecidas e sem a correspondente cartografação geomorfológica. O levantamento também salienta o fato de haver poucos dados disponíveis sobre a degradação do permafrost andino de altitude. Esta degradação, causada pelos processos de aquecimento global, deveria ser monitorada, entre outras, por razões hidrológicas. Os principais processos criogênicos - como criometeorização, nivação, solifluxão, crioturbação e seleção — são descritos em diferentes litologias, lugares, etc.. São fornecidos alguns dados quantitativos sobre movimentos de solifluxão e aplicação de métodos sedimentológicos na detecção de fenômenos criogênicos. São resumidos os últimos dados sobre permafrost andino, obtidos com o auxílio de métodos geofísicos e/ou sondagens acompanhadas de medidas da temperatura do solo. As formas criogênicas mais comuns nos Andes são apresentadas: microformas, patterned ground, felsenmeer, estruturas de crioturbação, thufurs em moors e lobos de solifluxão. Mesoformas características dos rock glaciers dos Andes Centrais e elementos importantes de ambiente periglacial como vertentes criogênicas de sedimentação, superfícies de crioplanação ou vales assimétricos são também descritos.

Palavras-chave: Geocriologia - permafrost - periglacial - Andes - regiões criogênicas - Geomorfologia

\section{ABSTRACT}

This geocryological inventory contributes to the state of the art and to recent advances of Geocryology in the countries of South America with permafrost occurrence or seasonally frozen ground, where this field of research is of scientific interest. The aim is to increase the knowledge about the areas of the present cryosphere being modified by man and/or suffering changes due to climatic factors. A brief climatic analysis helps to understand the main South American cryogenic regions still poorly known and lacking the corresponding geomorphological cartography. The survey also emphasizes the fact that very few data are available on altitudinal Andean permafrost degradation caused by global warming processes, which should be monitored for hydrological and other reasons.

The main cryogenic processes observed such as cryometeorization, nivation, solifluction, cryoturbation and sorting are described in different lithologies, places, etc. Some quantifications are given, such as data on solifluction movements and sedimentological methods applied to detect cryogenic phenomena. The latest data of Andean permafrost are summarized. They have recently been obtained with the help of different methodologies, including geophysics and/or.through borehole with ground temperature measurements. The most common Andean cryogenic forms are presented: microforms, patterned ground, felsenmeer, cryoturbation structures, thufurs in moors and solifluction lobes. Characteristic mesoforms of the Central Andes, rock glaciers, or important elements of a periglacial environment such as sedimentary cryogenic slopes, cryoplanation surfaces or asymmetrical valleys are also described.

Keywords: Geocryology - permafrost - periglacial - Andes - cryogenic regions - Geomorphology 


\section{INTRODUCTION}

Geocryology is the science that studies the environment and the ecology of cold regions, their natural, geological and physico-chemical processes in relation with cycles of freezing and thawing as well as the relation between all those phenomena and human life.

The original concept periglacial (introduced by Walery von Lozinski on the Eleventh International Congress of Geology in Stockholm in 1910), originally applied to describe the climatic and geomorphologic processes in areas close to Pleistocene ice, was complemented by the Russian term Geocriologija (NAUK AKADEMIJA 1960) for its wider concept referring to low temperatures, with permanently or even short term, seasonal or daily frozen ground.

When the ground, like soil, rock and organic material, remains at or below $0^{\circ} \mathrm{C}$ for at least two consecutive years, it is called permafrost (VAN EVERDINGEN 1998).

High latitudes together with a low MAAT (mean annual air temperature) are conditioning factors for the occurrence of Antarctic permafrost and for permafrost of subantarctic islands. In our case the altitude provides the basis for us to classify permafrost as mountain permafrost of the Andean type. However the variety of dry permafrost with temperatures below zero but without ice is also a frequent phenomenon, and should not be neglected when considering cryotic characteristics of the Central Andes and the region of the South American Dry Diagonal or the Desert Andes.

It is the aim of this work to present the state of the art and recent advances of Geocryology in the countries of South America with permafrost occurrence or seasonally frozen ground and where this field of research is of scientific interest.

The future role of Geocryology has to be emphasized because it may provide important insight to the paleoclimatic reconstruction in climate changes and hydrology in South America.

\section{PERMAFROST}

One of the first attempts to map cryogenic regions in South America was made by BARANOV in 1964.

The map of MAAT of South America by HOFFMANN (1975) (Fig. 1, adapted by Trombotto) and the lines for $+5,0$ and $-5^{\circ} \mathrm{C}$ may help to determine locations with possible permafrost as well as the most important areas with seasonal freezing or periglacial phenomena. Some areas require more specific information (e.g. the coldest site in South America in Patagonia, ice covers).

From the $>13$ million $\mathrm{km}^{2}$ that correspond to the permanently frozen ground in the Southern Hemisphere, the largest part is that of the Antarctica, whereas there is very few data about permafrost occurrence on the South American continent.

Some estimations held that mountain permafrost would cover approximately 30,000 $\mathrm{km}^{2}$ (GORBUNOV 1978), but recently it is assumed that it covers even $270,000 \mathrm{~km}^{2}$ (HAEBERLI et. al. 1993). They divided permafrost into maritime permafrost in the Southern and Tropical Andes and continental permafrost in the Central Andes.

In Argentina the term of approximately continuous permafrost (as introduced by GARLEFF \& STINGL 1986) is applied to the type of permafrost which is very much restricted by topography and is limited to the MAAT isotherms of $-2{ }^{\circ} \mathrm{C}$ and $-4{ }^{\circ} \mathrm{C}$ (at the Central Andes, $33^{\circ} \mathrm{S}$ and approximately $4500 \mathrm{~m} \mathrm{ASL}$ ) with precipitations between $500-900 \mathrm{~mm} / \mathrm{y}$ and limited to the isotherms of $-1^{\circ} \mathrm{C}$ and $-2^{\circ} \mathrm{C}$ with a precipitation of $300 \mathrm{~mm} / \mathrm{y}$ in the case of the Argentine Puna region (Table 1).

The lower limit of Andean permafrost is restricted by a type of discontinuous permafrost (Table 1, Fig. 2) which may be observed in some parts through rock glaciers (BARSCH 1977). At present the lower permafrost limit at the Cordón del Plata (Central Andes, Mendoza) is found at an elevation of $3700-3800 \mathrm{~m}$. In the Southern or Wet Andes, the so-called Patagonian Andes, the occurrence of permafrost was registered at $51^{\circ} 30^{\prime} \mathrm{S}$ in Santa Cruz (ROIG 1986) at an elevation of $980-1100 \mathrm{~m}$ in the years 1977 and 1978. In the Lake Region between $35^{\circ}$ and $45^{\circ}$ $30^{\prime} \mathrm{S}$, in the province of Chubut however, permafrost near Lake Vintter (approximately $44^{\circ} \mathrm{S}$ ) had been registered at an elevation of 2060 $m$ in recent years (C. Bianchi, pers. comm., 1998).

The term island permafrost (Table 1) was introduced for the phenomenon of isolated patches at $4000 \mathrm{~m}$ ASL in the Central Andes of Mendoza (TROMBOTTO 1991) and relict permafrost for frozen ground at $3400 \mathrm{~m}$ but with a thick detrital cover in rock glaciers.

Towards the Equator, in the region of the Chimborazo (6275 m ASL, Ecuador), a typical 


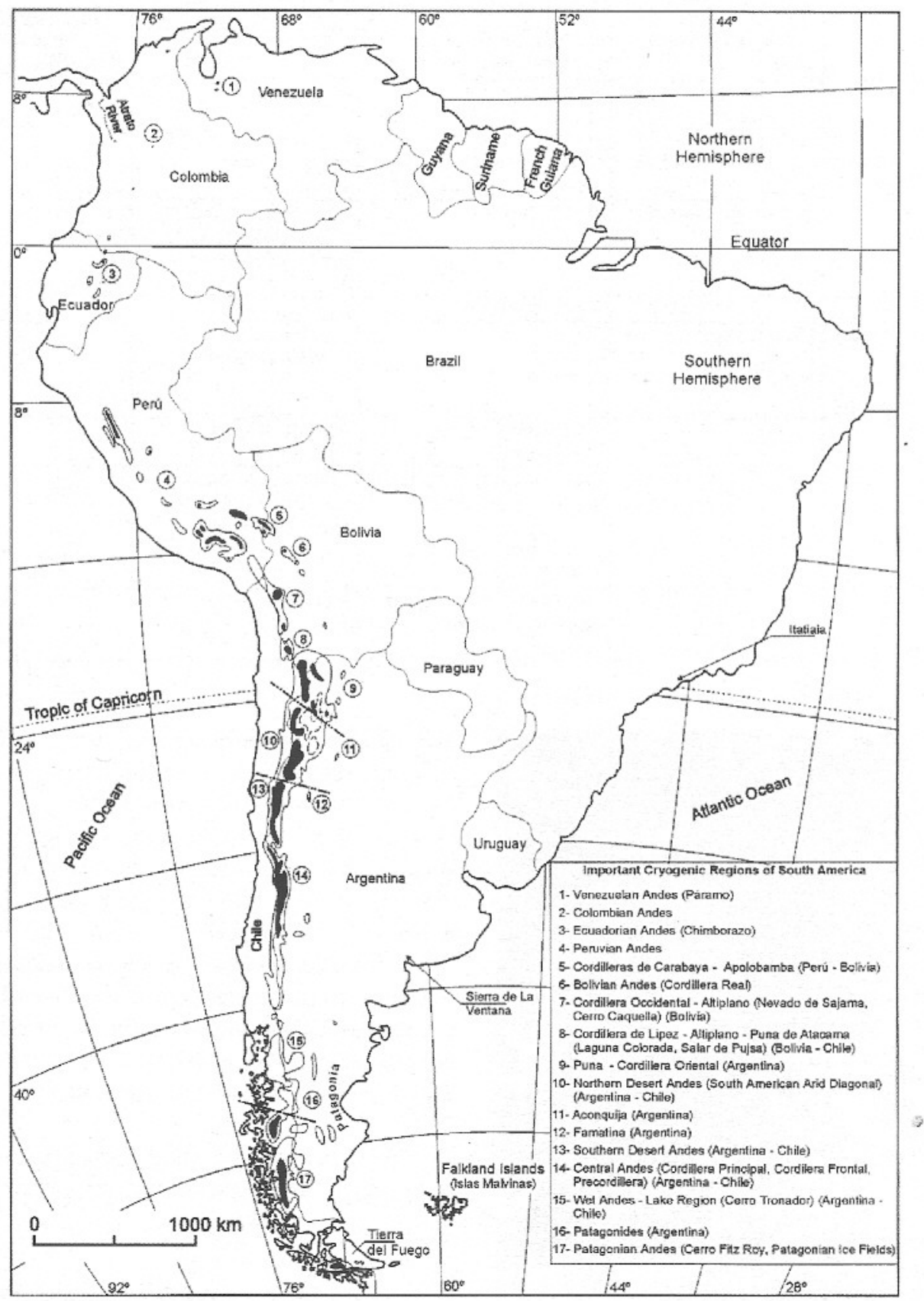

FIGURE 1 - Important Cryogenic Regions and MAAT map of South America (adapted by Trombotto) Black: MAAT $0-(-5)^{\circ} \mathrm{C}$ (including ice covers); dash line: MAAT $>5^{\circ} \mathrm{C}$

tropical environment but with dry conditions, HEINE (1994) reported the limit of continuous permafrost to be at $5250-5300 \mathrm{~m} \mathrm{ASL}$. Island permafrost, also mentioned by the author, is found below $5000 \mathrm{~m}$. In other parts of the Andes of Ecuador, with soil temperatures around $0^{\circ} \mathrm{C}$ but under humid conditions, there is no permafrost, but a glacial environment.

At the same time, subterranean ice may be preserved as in the case of inactive ice (Table 1) found at the salt lakes in the Altiplano and Puna of Atacama (Bolivia and Chile) at $4300 \mathrm{~m}$ and approximately $22^{\circ} \mathrm{S}$ (HURLBERT \& CHANG 1984) who assigned this type of ice to the Little Ice Age.

Thermic particularities and regional dry conditions seem to reinforce the effects of periglacial processes and the persistence of ground ice in the Central Andes. Between 1991 and 1993 


\begin{tabular}{|c|c|c|c|c|}
\hline \multirow{2}{*}{$\begin{array}{c}\text { Permatrost } \\
\text { Type }\end{array}$} & \multirow[b]{2}{*}{ Tropical Andes } & \multicolumn{2}{|c|}{ Dry Andes } & \multirow{2}{*}{$\begin{array}{c}\text { Southern } \\
\text { Andes } \\
\left(35^{\circ}-55^{\circ} 30^{\prime} \mathrm{S}\right) \\
\end{array}$} \\
\hline & & $\begin{array}{l}\text { Desert Andes } \\
\left(17^{\circ} 30^{\prime}-31^{\circ} \mathrm{S}\right)\end{array}$ & $\begin{array}{c}\text { Central Andes } \\
\left(31^{\circ}-35^{\circ} \mathrm{S}\right)\end{array}$ & \\
\hline $\begin{array}{l}\text { Continuous } \\
\text { "Approximately } \\
\text { Continuous" }\end{array}$ & $\begin{array}{l}\text { Chimborazo ( } 6275 \\
\text { m). Ecuador, inf. } \\
\text { limit: } 5250-530( \\
\text { m ASL (above sea } \\
\text { level) }\end{array}$ & $\begin{array}{l}\text { NW Argentina } \\
-1 /-2^{\circ} \mathrm{C} \text { air isotherms } \\
\text { and }<300 \mathrm{~mm} / \mathrm{y} \\
\text { "Glatthaenge", } \\
\text { cryoplanation surfaces }\end{array}$ & $\begin{array}{l}-2 /-4^{\circ} \mathrm{C} \text { air } \\
\text { isotherms and } 500 \text { - } \\
900 \mathrm{~mm} / \mathrm{y}, \text { summit } \\
\text { cryoplanation } \\
\text { surfaces }\end{array}$ & $1+0,0 \mathrm{cos}$ \\
\hline Discontinuous & Active rock glaciers & $\begin{array}{l}\text { Rock glaciers } \\
>175 \mathrm{~mm} / \mathrm{y}\end{array}$ & $\begin{array}{l}\text { Active rock glaciers } \\
\text { as indicators in the } \\
\text { sense of Barsch } \\
(1977)\end{array}$ & $\begin{array}{l}\text { Active rock } \\
\text { glaciers }\end{array}$ \\
\hline Sporadic & & Rock glaciers & Rock glaciers & \\
\hline $\begin{array}{l}\text { Insular or island } \\
\text { Isolated patches }\end{array}$ & $\begin{array}{l}\text { Chimborazo, } \\
\text { Ecuador } \\
<5000 \mathrm{~m} \mathrm{ASL}\end{array}$ & & $\begin{array}{l}\text { "cryobasin of } \\
\text { cryosediments" }\end{array}$ & \\
\hline Dry & & $\begin{array}{l}\text { South American Dry } \\
\text { Diagonal (?) }\end{array}$ & Detritic slopes & - \\
\hline $\begin{array}{l}\text { "Warm" } \\
\text { mountain } \\
\text { Degraded }\end{array}$ & & $\begin{array}{l}\text { Rock glacier, Constant } \\
\text { ice temperature at } \\
-1.6^{\circ} \mathrm{C} \text {, } \\
\text { Low resistivities } \\
>20000 \Omega \mathrm{r}\end{array}$ & $\begin{array}{l}\text { Low resistivities in } \\
\text { "cryobasin of } \\
\text { cryosediments" }\end{array}$ & \\
\hline $\begin{array}{l}\text { Relict } \\
\text { Relict ice }\end{array}$ & & $\begin{array}{l}\text { Salt lakes in the Puna } \\
\text { de Atacama and } \\
\text { Altiplano }\end{array}$ & Rock glaciers & \\
\hline
\end{tabular}

IABLE 1 - Andean Permatrost 1ypes in South America

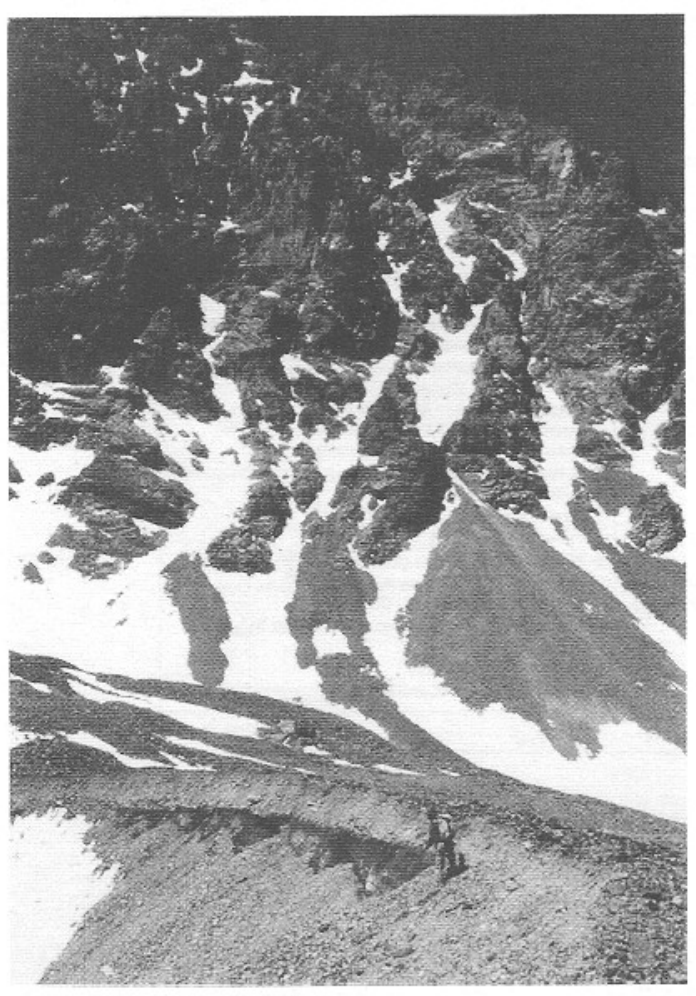

FIGURE 2 - Andean permafrost and thermokarst at Cordón del Plata, Central Andes, Mendoza, $4600 \mathrm{~m}$ ASL (November 1999). The observer indicates the limit between permafrost table and active layer

the $0^{\circ} \mathrm{C}$ isotherm at the Cordón del Plata (Andes of Mendoza, Argentina) was found at $3865 \mathrm{~m}$ (TROMBOTTO et al. 1997), most probably influenced by the warming process in the 1980's, cryogenic processes however influenced at much lower elevations.

Signs of activity in the rock glaciers of Mendoza for example establish lower limits of permafrost; and thus the designation island permafrost (TROMBOTTO 1991).

Additional investigations are required for the distribution of Andean permafrost. It is necessary to map it, to study its topography, its ice content and its behaviour regarding global climatic change as well as its importance to domestic water supply.

\section{INVENTORY OF CRYOGENIC PROCESSES OBSERVED IN SOUTH AMERICA}

The main cryogenic processes observed in the South American Andes are cryoweathering (Fig. 3), nival processes, solifluction, cryoturbation, sorting, frost cracking and permafrost creeping with different lithologies. Some sites are being monitored. The studies of the processes in the periglacial environment in the laboratory and in the field were principally guided by the following phenomena.

- Sorting: sorted materials due to cryogenesis create a cryogenic law, represented by pebbles and cobbles above and sediments below. CORTE (1962 a, 1962 b) confirmed this law in experiments 


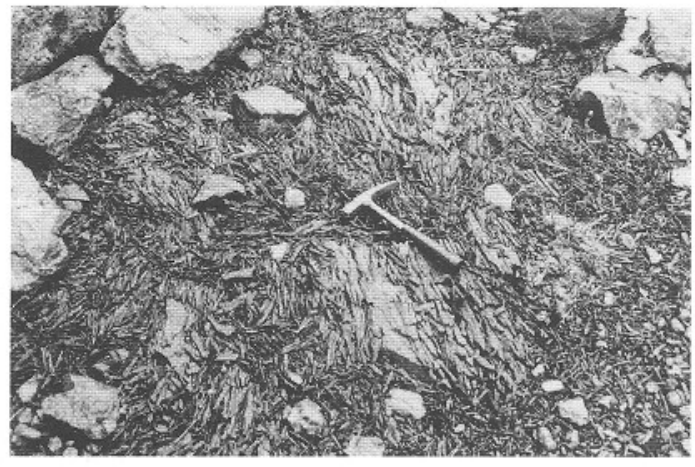

FIGURE 3 - Cryoweathering at Cerro Hatcher, Sierra de Sangra, Southern Andes, 915 m ASL, 48 $29^{\prime} \mathrm{S}$ and $72^{\circ} 14^{\prime} \mathrm{W}$. Length of the hammer: $31.8 \mathrm{~cm}$ (December 1999).

in the 1960's. Repeated cycles of freezing and thawing may cause a sedimentary sorting of material, creating a cryogenic law this way that determines in which kind of landscapes a periglacial environment coarse sediments $(>2 \mathrm{~mm}$ ) is found above or below fine sediment. CORTE (1962a) reproduced in the laboratory the segregation of ice and the sorting of a granulometrically heterogeneous mixture, saturated with or without silt particles $<0.02 \mathrm{~mm}$. The presence of silt has an important granulometrical significance to generate frost heaving. With water flow and the growth of ice the transport of material in its open system is to be explained. On the other hand it is assumed that the upward movement of blocks leaves a space quickly filled by fine material that stops the blocks from settling during the thawing process.

- Proceeding in a similar way AHUMADA (1987), in her doctoral thesis, proved the same (sorting) for heavy minerals in the active layer.

- I mportant phenomena related with silica deposition in periglacial environments were part of TROMBOTTO's (1988) research for his doctoral thesis.

- As to important cryogenic chemical phenomena VOGT \& CORTE (1996) had observed for a long time the possible origin of $\mathrm{CaCO}$.

- Desiccation cracks and thermal contractions were very much discussed among geologists in South America. The dehydration process of the Pleistocene active layer and thermal contraction may often use the same cracks (TROMBOTTO 1996).
- In comparison to other sedimentary media there is no data about fluvial phenomena. Under the impact of winds in Mendoza taffonis of cryogenic - petrologic origin could be observed on pyroclastic rocks at $34^{\circ} \mathrm{S}$. Loess is still discussed as an aeolian sediment, but a cryogenic component in its origin cannot be ruled out. As TROLL (1944) assumed, freezing is an essential phenomenon in order to explain the production of silt in the loess. It may well be that the Patagonian loess material (TROMBOTTO 1996) as well as the Andean silt or cold loess was influenced by cryogenesis. TROMBOTTO \& REGAIRAZ (2000) have recently described a case of cold loess for Mendoza.

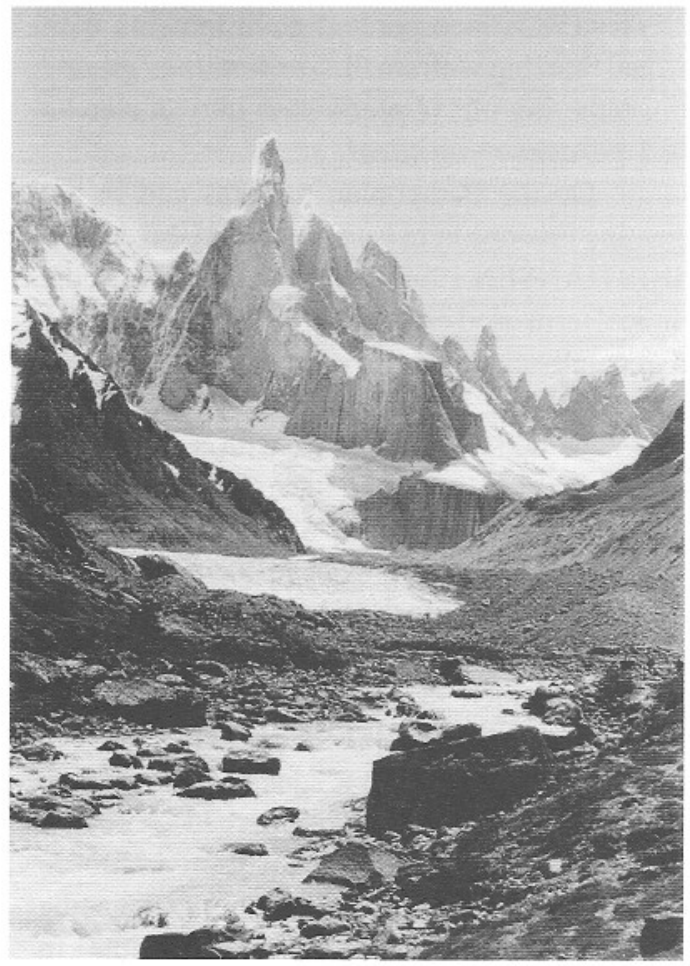

FIGURE 4 - Torre (3102 m ASL), Egger and Standhardt, Chalt, Adela glacier, Southern Andes, Santa Cruz, Argentina, ca. $49^{\circ} 15^{\prime} \mathrm{S}$ and ca. $73^{\circ} 05^{\prime} \mathrm{W}$ (December 1998).

- Among the cryogenic processes of the Andean cycles of freezing and thawing, the mechanisms of different South American lithologies and their experimental correlation are yet unknown (Fig. 4). The cycles have to be reproduced in order to simulate the observed natural conditions as in the Central Andes for example, with a low content of humidity and high amplitudes and temperature oscillations between $+30^{\circ} \mathrm{C}$ and $-20^{\circ} \mathrm{C}$ within 24 hrs. 
Trollbrot is one example of an Andean cryogenesis, where the fragments remain together and resemble sliced bread.

\section{SEASONAL FROZEN GROUND}

The area affected by seasonal freezing in South America, and Argentina in particular, is much larger than that covered by permafrost.

The important processes are solifluction and the effects of needle ice. The action of the wind or the impact of solar radiation combined with cryogenesis have been studied by PÉREZ (1984, 1992).

In the Central Andes of Mendoza, CORTE (1983) incorporated environments with seasonal freezing with small-size patterned ground and weathering pits (Opferkessel) into an area he called parageocryogenical.

On the Patagonian mesetas and in the Argentine Precordillera keppavond (HUMLUM \& CHRISTIANSEN 1998) may be found. This is the technical term used on the Faeroe Islands to define active small-scale patterned ground.

ANGELINI (1990) and BUK (1992) made maps delimiting regions with a maximum seasonal freezing index and mean annual freezing frequencies in Patagonia. Segregation ice or pipkrake has a strong impact in these areas and influences works of civil engineering in road construction (Patagonia). Although no permafrost has been detected in the Andes of Mérida and Sierra de Perija (Venezuela), the periglacial level of these processes may reach a zone of over $1000 \mathrm{~m}$ above $3600 \mathrm{~m} \mathrm{ASL}$. Sorted patterned ground is characteristic of the Páramo. At the Páramo de Piedras Blancas (Venezuela) the limit of needle ice for example, lies at an elevation of $3600 \mathrm{~m}$ (SCHUBERT 1979). In the region of the Tropical Andes, the phenomena of seasonal freezing are concentrated on an area called Tierra Helada which lies above the timberline, with a MAAT of $7^{\circ} \mathrm{C}$ (subpáramo) to a MAAT of $-1,5^{\circ} \mathrm{C}$ at the snowfall level (Pico Bolívar, $5008 \mathrm{~m}$ ASL) in the so-called superpáramo (LAUER 1979).

Two superficial miniature forms that may be observed in these areas affected by the growth of needle ice and its pressure are gaps and miniature stripes. The gaps, or gaps around stones (WASHBURN 1979), are little mounds produced by needle ice and characterized by rocks that were lifted by upheaval and are left in position. Posterior to and frequently after this phenomenon a certain discontinuity or a ring with an empty space between the rock and the sediment is found. As WASHBURN (1979) pointed out needle-ice occurred even in Brazil.

On the other hand the needle ice leaves different microstructures. They are usually crumbly and therefore they are called lumpy surfaces. Their appearance resembles plowed lands (WASHBURN 1979). SAPPER (1915, see WEISE 1983) introduced the term Rasenabschälung; a related term referred not directly to forms but to processes, but applied to peat areas.

\section{FLUVIAL AND AEOLIAN PROCESSES IN A PERIGLACIAL ENVIRONMENT}

In a cryogenic environment rivers and streamlets remain frozen during some time of the year. When they are not frozen they play an active role in the denudation of the valleys, although this fact is generally ignored.

Streamlets help to increase erosion in areas with permafrost and contribute to the formation of subterranean ice. Streams and subterranean ice extruded by freezing of some parts of the ground also create the characteristic ice in various layers called icing or Aufeis. It is formed by the successive flow of water that freezes and is then covered by a following flow that freezes and so on. This phenomenon may be frequently observed in the Andes.

The influence of the wind is also decisive for the shaping of either continental or coastal cryogenic forms. A great variety of aeolian forms are found in cryogenic environments.

Clasts and blocks with one or more surfaces shaped by the wind are designated ventifacts of cold environments. Depending on how many sides are eroded by the wind they are called 1: Einkanter, 2: Zweikanter and 3: Dreikanter (terms of German origin). The eroded surfaces are used to determine the wind direction (GONZÁLEZ BONORINO \& TERUGGI 1952). These ventifacts are part of the desert pavement so typical for the Andean aeolian periglacial environments. Rock cavities caused by aeolian erosion and with some participation of chemical weathering in their genesis are called taffoni (see FRENCH 1988).

These taffoni or honeycomb forms are stones with concavities produced by aeolian erosion (FRENCH 1988), usually in granitic rocks. The erosion of sandstone in a periglacial 
environment may produce mushroom shaped structures. AUER (1956) described mushrooms as relicts of sandstone for Tierra del Fuego. In the protected area of Laguna del Diamante $\left(34^{\circ} \mathrm{S}\right.$, Cordillera Principal) some excellent examples of erosion, particularly in tuff or pumice, may be observed.

Another sediment of aeolian origin or of periglacial genesis is the covering debris (Deckschutt) in the so-called dells or periglacial valleys, with a very important aeolian component. The covering debris represents a diagnosis of the geoforms of cryogenic origin. Cold loess is mentioned by HAMELIN \& COOK (1967) referring to the loess deposited in the surroundings of glaciers. Generally the loess consists mainly of $50-60 \%$ silt (< than $0.06 \mathrm{~mm}$ ), $5-30 \%$ clay, and 5 $-10 \%$ sand. These values may vary by about $10 \%$.

The most outstanding loess deposits of the Southern Hemisphere are those of the Pampean Plains. In comparison to other loess they possess an important textural component of fine sand and volcanic glass. These deposits consist of $50 \%$ silt, $50 \%$ sand and reveal a high content of volcanic ashes and plagioclases. Predominant heavy minerals are hornblende, hypersthene, and augite. These loess were assigned to an arid climate, but not as indicators of cold climates (TERUGGI 1957).

However, a loess profile located at Las Carreras Valley, on the foot of the Cordón del Plata, an eastern range of the Central Andes, in the province of Mendoza, Argentina, was dated with thermoluminescence. It was assigned to the Middle Pleistocene and would express a cryomere of almost $200 \mathrm{ka}$ that may be correlated with the corresponding glacial episode in the Northern Hemisphere. This fact identifies this profile as a key element for the Quaternary stratigraphy in South America.

On the other hand it cannot be ruled out that for the silt-loess material from Patagonia (Camwy Formation, TROMBOTTO 1996) during the cryomeres or cold episodes, cryogenesis was involved. As early as 1936 GROEBER pointed out an important cryogenic relation between cold Andean environments and mechanical weathering. This author however, was looking for an explanation of the old "Bonaerense" and the Pampean Plains as well as for the sands called "Médano Invasor" (Invading Dunes).

Recently this last theory was presented again by IRIONDO \& KRÖHLING (1995). They used this theory to explain the origin and the deposition of sandstone and loess sediments of the Pampean region up to the south of Brazil during the dry episodes from IS4 onwards, considered to be the coldest episode of the last cycle (?). It still is difficult to trace back the provenance of the silt, and the techniques for the exact identification of its genesis are somewhat limited.

\section{CHARACTERISTIC CRYOGENIC LANDSCAPES OF SOUTHERN SOUTH AMERICA}

\subsection{Mesas or sugar-loaves (HURLBERT \& CHANG 1988)}

Mesas are flat mounds referring to Chilean - Bolivian permafrost areas (about $1 \mathrm{~km}^{2}$ ) in relation with shallow saline high mountain lakes, as Laguna Colorada and Salar de Pujsa (over $4000 \mathrm{~m} \mathrm{ASL}$ ) in the Desert Andes, which hide in their interior strata of pure ice, veinlets or frozen sediments.

They are found in areas with an active layer rich in clay and silt with calcite (eventual thenardite), which enhances the strong reflection in isolation. The ice content varies between $10-87 \%$, with a thickness between $1 \mathrm{~mm}$ and $1 \mathrm{~m}$. The maximum thickness of the permafrost in this area is assumed to be $25 \mathrm{~m}$ (GORBUNOV 1993) and the permafrost table lies between 20 and $70 \mathrm{~cm}$. While HURLBERT \& CHANG $(1984,1988)$ believe them to be relicts form the Little Ice Age, GORBUNOV (1993) thinks they are relicts from the Late Pleistocene to Upper Holocene.

\subsection{Patterned ground}

Patterned ground is characterized by a combination of processes with the intervention of frost heaving caused by needle ice, sorting, soil creep, dehydration and thermal contraction caused by the action of freezing and thawing.

According to WASHBURN's (1970) important classification, the most important forms of patterned ground in South America have been grouped into: nets, stripes, polygons and circles (Table 2). They may be distinguished by their respective geometries. They are designated sorted or unsorted according to their textural differences and the definition of shape.

Nets (Fig. 5) or irregular shapes (Fig. 6) without permafrost but closely linked to the 
problems of night frost according to TROLL (1944) appear in the Tropical Andes. As PÉREZ (1984) proved, the genesis of patterned ground in the mountains of Venezuela is influenced by solar radiation above all other factors.

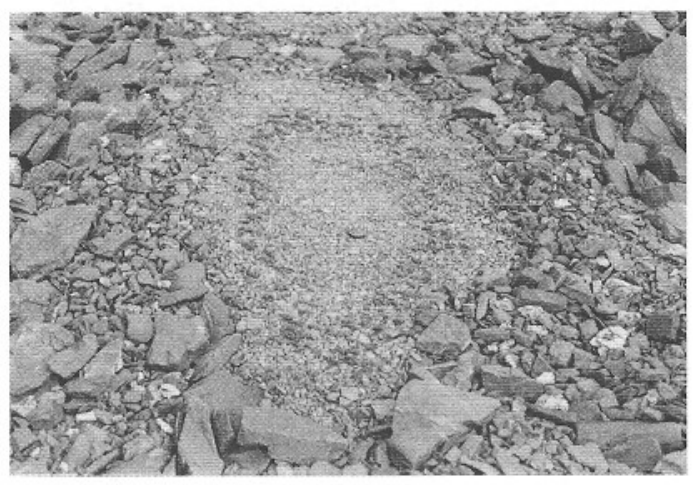

FIGURE 5 - Sorted nets and extrusion structures, at the Lagunita del Plata, Cordillera Frontal, Mendoza, Argentina, $4000 \mathrm{~m} \mathrm{ASL}$, ca. $33^{\circ} \mathrm{S}$ and ca. $69^{\circ} \mathrm{W}$. Diameter of the camera lid: $5.4 \mathrm{~cm}$ (March 1996).

The nets are usually of small size, in the range of a few centimeters, but under certain favourable conditions and with a more complex genesis as in the Central Andes, they reach the ranges of meters (Fig. 6). These shapes may also be the result of cryoturbation. Desiccation fissures also favour the formation of nets and there are cases of stripes combined with thermal contraction cracks.

For some time we have records of schist stripes in Peru (TROLL 1944) and in the Argentine

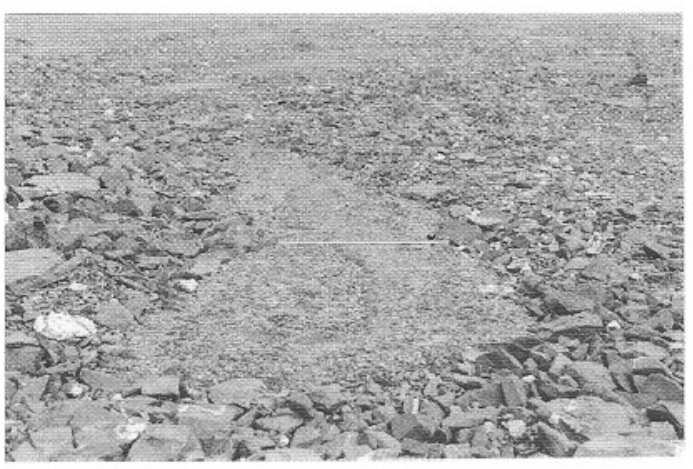

FIGURE 6 - Sorted nets in transformation into stripe in sense of Büdel (1981), at the Lagunita del Plata, Cordillera Frontal, Mendoza, Argentina, $4000 \mathrm{~m}$ ASL, ca. $33^{\circ} \mathrm{S}$ and ca. $69^{\circ} \mathrm{W}$. Length of the measure: $1 \mathrm{~m}$ (March 1996).

Andes (CORTE 1953). They are 10 to $30 \mathrm{~cm}$ wide, and sometimes limited by other stripes with coarser material of similar size (sorted stripes). GRAF (1971) mentioned giant stripes that occurred at elevations between 4800 and $4950 \mathrm{~m}$ in Perú. Stripes combined with thermal contraction fissures are usually found in the Central Andes of Mendoza with large and angular shaped clasts where the fine material is not hed out be melting water. At the Lagunita del Plata, Argentina, the stripes are predominantly of greywacke. They reveal, in thermal contraction fissures, a characteristic collapse fabric as the clasts fall into the fissures with their main axes vertically oriented (TROMBOTTO 1991).

Stone polygons (Fig. 8) occur closely related with dehydration of the soil during winter

\begin{tabular}{|c|c|c|}
\hline Pattern & $\begin{array}{c}\text { Locations } \\
(\varnothing=\text { diameter })\end{array}$ & References \\
\hline Nets & $\begin{array}{l}\text { Peruvian Andes and the Cordillera Real } \\
\text { in Bolivia, } 4600 \text { and } 5300 \mathrm{~m} \mathrm{ASl} \\
\text { (above sea level) }\end{array}$ & $\begin{array}{l}\text { TROLL (1944) } \\
\text { GRAF (1971) }\end{array}$ \\
\hline Nets & $\begin{array}{l}\text { Cordillera Principal of Mendoza, at } \\
3.300 \mathrm{~m} \text { at } 34^{\circ} \mathrm{S}(\varnothing 15-20 \mathrm{~cm} \text { ) and at } \\
3.800 \mathrm{~m} \text { and above }(\varnothing 1 \mathrm{~m}) \\
\text { At the Quebrada del Matienzo ( } 3600 \mathrm{~m} \text {, } \\
\left.33^{\circ} \mathrm{S}\right) \varnothing 20 \mathrm{~cm} \text { with cryoturbation } \\
\text { processes }\end{array}$ & $\begin{array}{l}\text { CORTE (1953) } \\
\text { AHUMADA }(1987,1992)\end{array}$ \\
\hline Nets & $\begin{array}{l}\text { Central Andes of Mendoza, Argentina, } \\
\varnothing: 5 \mathrm{~m} \text { (Figs. } 5 \text { and } 6 \text { ) }\end{array}$ & TROMBOTTO (1991) \\
\hline Stripes & $\begin{array}{l}\text { Páramo of Venezuela. Towards the } \\
\text { south and alongside the Andean chain. }\end{array}$ & $\begin{array}{l}\text { SCHUBERT (1979), PEREZ } \\
(1992)\end{array}$ \\
\hline Stripes & Perú & TROLL (1944) \\
\hline Stripes & Argentina (Fig. 7) & AHUMADA (1992) \\
\hline $\begin{array}{l}\text { Giant schist } \\
\text { stripes }\end{array}$ & $\begin{array}{l}\text { Laguna de Aguascocha", } \\
\text { Perú }\left(11^{\circ} \mathrm{S}\right)\end{array}$ & GRAF (1971) \\
\hline $\begin{array}{l}\text { Giant } \\
\text { Stripes }\end{array}$ & $\begin{array}{l}\text { At } 3800 \mathrm{~m} \text { near "Cerro de la Laguna" } \\
\left(34^{\circ} \mathrm{S}\right), \varnothing: 3 \mathrm{r}\end{array}$ & CORTE (1953) \\
\hline $\begin{array}{l}\text { Stone } \\
\text { polygons }\end{array}$ & $\begin{array}{l}\text { Andes of Peru, } \\
\text { Bolivia and Argentina } \\
\varnothing: 10-25 \mathrm{~cm} \text { (Fig. 8) }\end{array}$ & $\begin{array}{l}\text { TROLL (1944), CORTE (1953), } \\
\text { GRAF (1971), HASTENRATH } \\
(1971), \text { AHUMADA (1987) }\end{array}$ \\
\hline $\begin{array}{l}\text { Sorted } \\
\text { circles }\end{array}$ & $\begin{array}{l}\text { "Cordón del Plata", } 4000 \text { m, Mendoza, } \\
\text { Argentina, } \varnothing: 1.6-4.4 \mathrm{~m} \text { (Fig. 10) }\end{array}$ & TROMBOTTO (1991) \\
\hline
\end{tabular}

TABLE 2 - South American Examples of Patterned Ground 


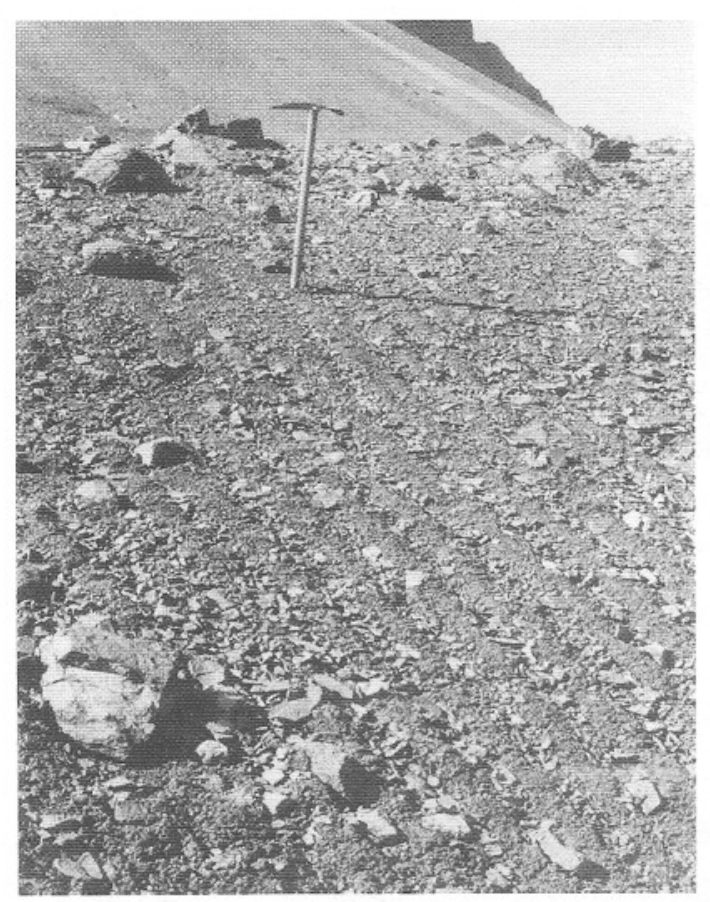

FIGURE 7 - Sorted stripes, Quebrada de las Bodegas or Matienzo, Cordillera Principal, Mendoza, Argentina ca. $32^{\circ} 40^{\prime} \mathrm{S}, 3700 \mathrm{~m}$ ASL (March 1984).

or with dehydration of layers saturated with melting water provided by snow patches or seasonal ice. Thermal contraction polygons (Fig. 9) are also frequently seen in the Central Andes.

The type of sorted stone circles (Fig. 10) with a depression in the centre are also called Amundsenrings (TROMBOTTO 1991).

Extrusion structures (frost boil, Frostbeule, ostiol) or tundra volcanoes (Figs. 6 and 11) are conical forms of fine sediments expelled by cryoturbation and cryostatic pressure in the substratum. They are frequently involved in the genesis of patterned ground. They may build micronets within circles or stone polygons or else contribute directly to the creation of stonenets.

During the thawing process these extrusion structures are flattened and they constitute isolated spots of fine material that resemble "cakes of sand or clay", which gave origin to the German name Erdkuchen apart from the term Frostbeule. They are frequently part of the sorted forms on the surface and they do not need permafrost. They are found very frequently throughout the Andean Cordillera.

The term nubbin (from middle low German: knot on a tree, applied by WASHBURN 1979) reaches back to a medieval Germanic word for a round protuberance sometimes prolonged

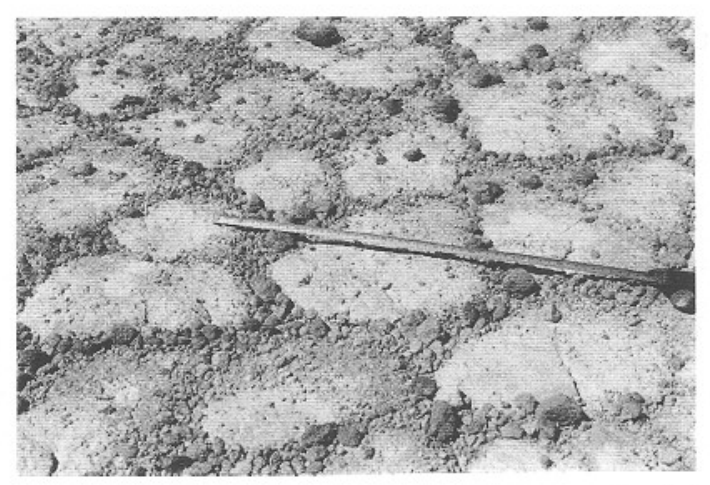

FIGURE 8 - Sorted stone Polygons, Laguna del Diamante, Central Andes, Mendoza, Argentina, $3220 \mathrm{~m} \mathrm{ASL}$, ca. $34^{\circ} 10^{\prime} \mathrm{S}$. Length of the measure: $50 \mathrm{~cm}$. (March 1995).

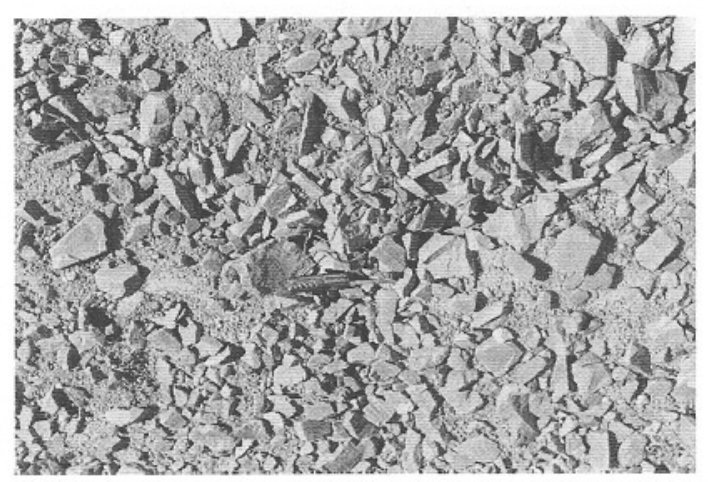

FIGURE 9 - Unsorted polygons, Pampa de los Avestruces, Central Andes, Mendoza, 3600 m ASL, ca. $34^{\circ} 10^{\prime} \mathrm{S}$. Length of the jack-knife: $9 \mathrm{~cm}$ (March 1995).

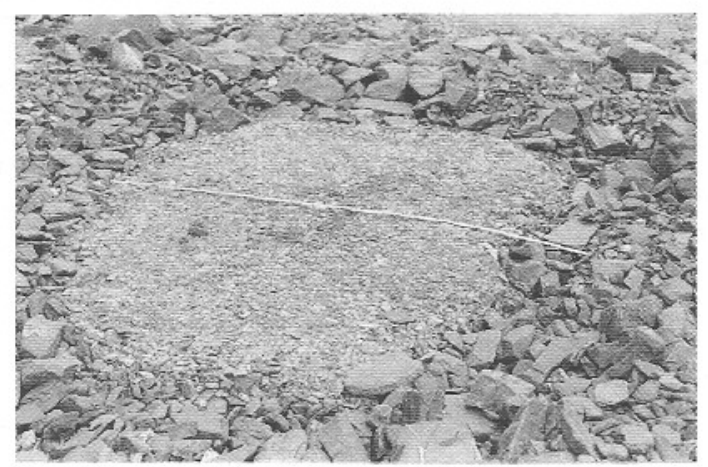

FIGURE 10 - Sorted circles, at the Lagunita del Plata, Cordillera Frontal, Mendoza, Argentina, about $4000 \mathrm{~m} \mathrm{ASL}$, ca. $33^{\circ} \mathrm{S}$ and ca. $69^{\circ} \mathrm{W}$. Length of the measure: $2 \mathrm{~m}$ (March 1996).

with fine material. The term nubbins was first used to describe those forms in Northeast of Greenland.

For WASHBURN nubbins are associated with the growth of needle ice including also Feinerdknospen, although Erdknospen in the Central Andes are defined as a result of extrusion with intervention of cryoturbation (TROMBOTTO 


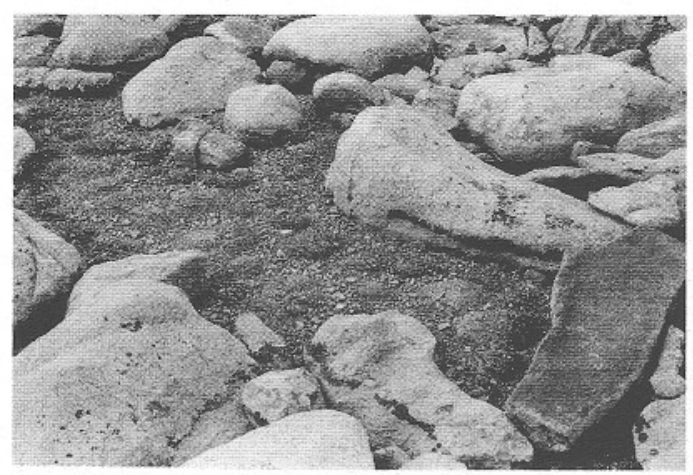

FIGURE 11 - Nubbins at the Lagunita del Plata, Cordillera Frontal, Mendoza, Argentina, about $4000 \mathrm{~m} \mathrm{ASL}$, ca. $33^{\circ} \mathrm{S}$ and ca. $69^{\circ} \mathrm{W}$.

1988). The mechanism of these arctic structures is called subduction. It is explained by DYKE \& ZOLTAI (1980) who calculate its movement to be less than $1 \mathrm{~mm}$ per year.

\subsection{Solifluction forms}

The slow creep downhill of saturated soil, caused by freezing and thawing in cryogenic regions is defined as solifluction. With permafrost it is called gelifluction. Some characteristic Andean forms are:

\section{- Solifluction sheets in the Central and Southern} Andes (Fig. 12). They are observed on surfaces with little inclination. They create forms interwoven or related with reliefs characterized by coarse sediments. They may be observed on slopes of $>2^{\circ}$. A type of solifluction layer with a reduced inclination angle contributes to the genesis of patterned ground or enhances solifluction contact.

\section{- Solifluction lobes (Fig. 13). They appear as} protuberances or tongues and may be identified on flanks of the slopes. Solifluction lobes may have terraced surfaces, rocky fronts and may have terraced surfaces, rocky fronts and may be combined with fissures provoked by the discharge of melting water at their frontal basis. In this last case the clasts are usually in vertical position. They are the classical product of macrosolifluction or slope solifluction as TROLL (1944) called it. The lobes may show a remarkable vertical sorting on their most superficial parts. At the Cordón del Plata, the lobes display angles between $28^{\circ}$ and $29^{\circ}$ mostly, with blocks between 30 and $40 \mathrm{~cm}$ on their surface and they are related

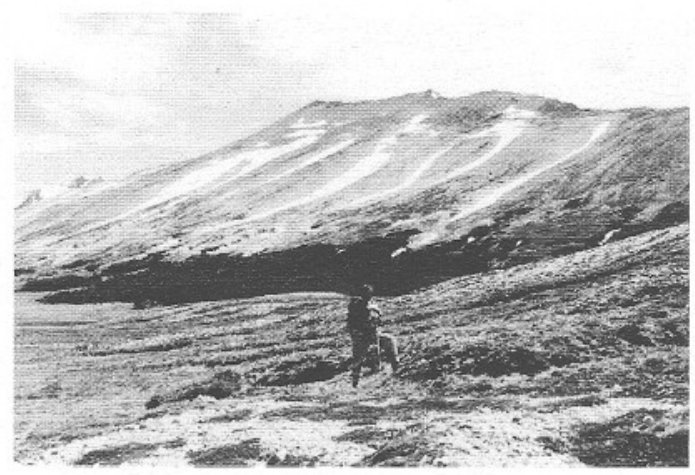

FIGURE 12 - Solifluction sheet, Cerro Hermoso valley, San Lorenzo Norte glacier, Southern Andes, Santa Cruz, Argentina, $1095 \mathrm{~m} \mathrm{ASL}, 47^{\circ} 34^{\prime} \mathrm{S}$ and $72^{\circ} 13^{\prime} \mathrm{W}$ (December 1999).

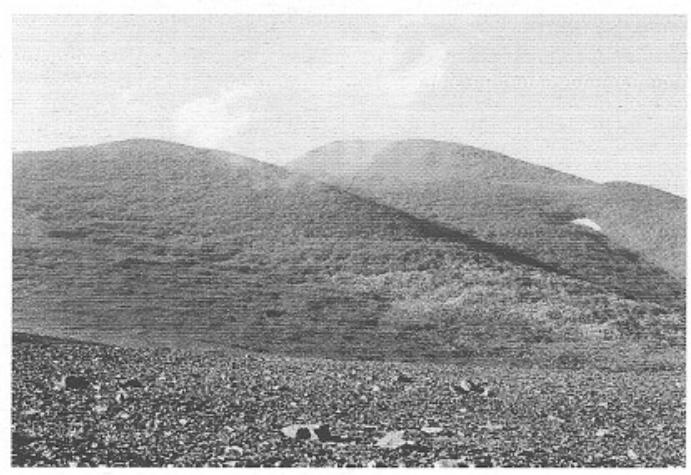

FIGURE 13 - Solifluction lobes, detrital slopes and snow hollow at the Lagunita del Plata, Cordillera Frontal, Mendoza, Argentina, 4000 - 4500 m ASL, ca. 33 S. (December 1983).

with the formation of debris slopes. The rate of movement of solifluction lobes in greywacke at the Lagunita del Plata ranged between 3 and $6 \mathrm{~cm}$ per year (1983 -1996). The maximum speed was registered at an elevation of $4300 \mathrm{~m}$ (TROMBOTTO et al. 1984, TROMBOTTO 1991).

- Solifluction terraces fréquent throughout the Andes. Solifluction terraces are relatively smallsized, stepped solifluction forms. They may appear combined with solifluction lobes and they do not require permafrost. In the entire Andean region these forms are most abundant. They reveal a vertical sorting with large quantities of fine sediments. They appear in a wide range of petrographical classes and with different inclination angles on the slopes. The most frequent slopes with terracettes in the area of the Lagunita del Plata, Cordón del Plata vary between $12^{\circ}$ and $25^{\circ}$. A particular type was identified in the Central 
Andes (TROMBOTTO 1991) because of its magnificence and because it is a geoform that appears in combination with snow patches. These giant forms, to be observed at the Lagunita del Plata, display solifluction processes in great steps in combination with the influence of snow patches, which persist for a long time in their frontal parts.

- Garlands (Fig. 14), terracettes and steps are solifluction forms whose frontal parts are contained or marked by vegetation or stones.

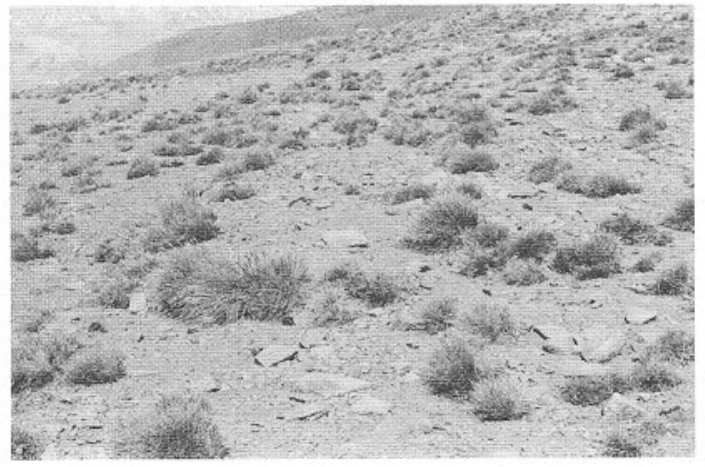

FIGURE 14 - Garlands, Laguna del Diamante, $3300 \mathrm{~m}$ ASL, ca. $34^{\circ} 10^{\prime} \mathrm{S}$. Diameter of the camera lid: $5.4 \mathrm{~cm}$ (March 1995).

Garlands do not require permafrost. It is a form of creep stopped or restricted by vegetation with a generally terraced surface. They were described extensively until approximately $5000 \mathrm{~m}$ where nets, stripes and small stone polygons appear, as in the Argentine Puna for example (IGARZÁBAL 1983). CORTE (1953) found garlands in Argentine, while trying to explain cryopedological phenomena at the Pampa de los Avestruces at an elevation of $3500 \mathrm{~m}$ (Mendoza). In Peru GRAF (1971), found them at $4850 \mathrm{~m}$ at the Valle Viscas ( $\left.11^{\circ} 35^{\prime} \mathrm{S}\right)$. In Chacaltaya, Cordillera Real in Bolivia, HASTENRATH (1971) registered them at $4500 \mathrm{~m}$.

In the Southern Andes, GARLEFF (1977) reported solifluction forms combined with or stopped by vegetation in the region of the cold woods of Araucaria and the subantarctic Magellan woods, above the timberline, or in the area of transition to periglacial soil (at Tronador at $1500 \mathrm{~m}$ and at the Fitz Roy at $1000 \mathrm{~m}$ approximately).

These authors also documented garlands in the Patagonian Sierras and the Patagonides, Argentina, at about $1000 \mathrm{~m}$ in the Sierra de Tecka and in San Bernardo for example. At the same time they mentioned lobes of blocks even with sorting for these elevations at the Patagonian plateaus (mesetas), and patterned ground at the Meseta de la Muerte.

- Rock streams (Fig. 15) were first described at the early century by a Swedish expedition to the Southern Andes and the Falkland Islands (HÖGBOM 1914).

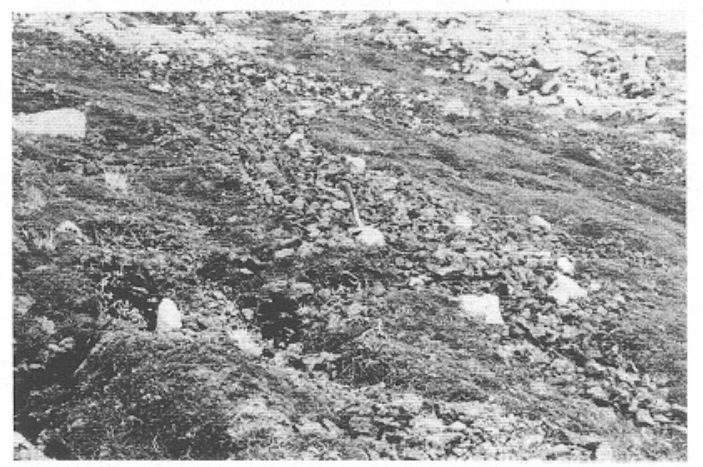

FIGURE 15 - Rock streams, Cerro Hermoso valley, San Lorenzo Norte glacier, Southern Andes, Santa Cruz, Argentina, $1365 \mathrm{~m} \mathrm{ASL}, 47^{\circ} 34^{\prime} \mathrm{S}$ and $72^{\circ} 13^{\prime} \mathrm{W}$ (December 1999).

Block tongues that move downhill by the effect of solifluction characterize the periglacial Andean level at different latitudes and elevations. Rock streams or stoneruns are a particular type of block tongues.

The term kurum used in the Transbaikal (ROMANOVSKIY et al. 1989) applies to rock streams or stoneruns whenever well-defined flows and detrital slopes or Schutthänge may be identified. These cover large extensions of the slope surfaces. These are regional forms and they depend on altitude and the humidity regime in the active layer, in other words on cycles of freezing and thawing. They move several $\mathrm{mm}$ per year. According to ROMANVOSKIY et al. (1989), they may be classified into: a) those created by basement rocks and b) those created by sedimentary sephitic rocks.

Wanderblocks or ploughing blocks are blocks that had been uplifted by the ice which slowly moves downhill due to solifluction. Sediments cover the side that is pushed.

They are found in the Andean Cordillera even in areas with seasonal freezing.

\subsection{Felsenmeer (block field, campo de bloques)}

A superficial layer of angular shattered rocks formed in either modern or Pleistocene periglacial environments (VAN EVERDINGEN 
1998). Felsenmeer are usually found on top of Andean cryoplanation surfaces (Fig. 16).

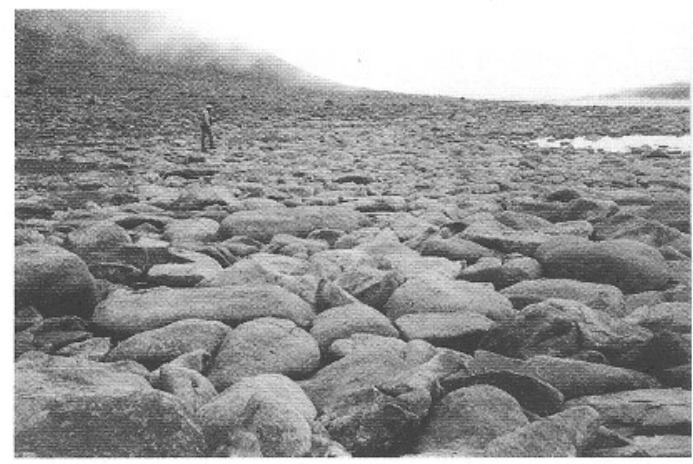

FIGURE 16 - Felsenmeer at the Lagunita del Plata, Mendoza, Argentina, ca. $4000 \mathrm{~m} \mathrm{ASL}$, ca. $33^{\circ} \mathrm{S}$ and ca. $69^{\circ} \mathrm{W}$.

BIGARELLA et al. (1969) found out that certain felsenmeer forms on the Plateau of Itatiaia, Brazil would correspond to a semiarid and cold episode of the Pleistocene. Other authors described these as a result of "cryoturbations" together with the shaping of pediments (see BIGARELLA et al. 1969). These relict forms of Itatiaia however rather seem to be related with "boulder streams" in the sense of MODENESI (1992) and CLAPPERTON (1993) and the indirectly involved periglacial process would correspond to the solifluction of subjacent sedimentary levels. This former fact is very important and would have to be analyzed with more detail, as it might represent the most northern paleoclimatic limit of periglacial phenomena outside the Andes.

\subsection{Nivation hollows}

Whether snow patches really react as erosive agents in cryogenic environments and at the snow-covered ground in mountain areas, without the participation of other factors, is questioned by HALL (1998). Another possibility to consider in relation with Andean nivation hollows is that they can indicate climate fluctuations as well as climatic changes.

Seasonal or perennial snow patches are characteristic of the Andean landscapes (Figs. 13 and 17). Snow patches seem to be strongly influenced by the El Niño / Southern Oscillation or ENSO phenomena and by snowfalls, in the Cordillera as well as by the observed processes of a warming up climate.

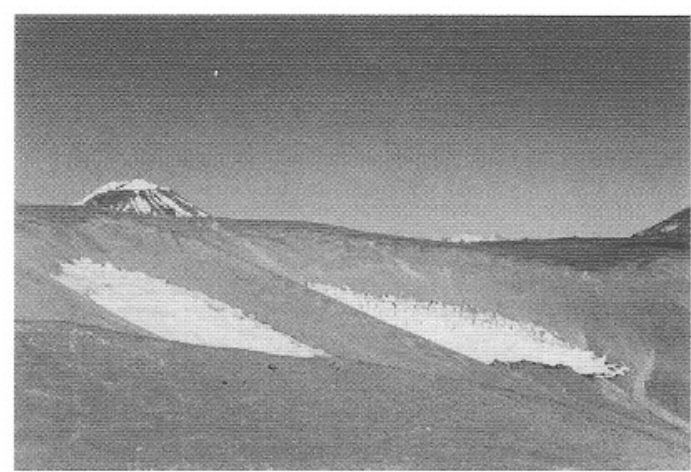

FIGURE 17 - Snow patches, cryoplanation surfaces, Laguna del Diamante, Mendoza, Argentina, ca $3500 \mathrm{~m} \mathrm{ASL}$, ca. $34^{\circ} 10^{\prime} \mathrm{S}$ (February 19.95).

The lower limit of perennial snow patches in the Andes of Mendoza $\left(33^{\circ} \mathrm{S}\right)$ lies at $4300 \mathrm{~m}$ on the south-facing slopes. In the Southern Andes $\left(38^{\circ} \mathrm{S}\right)$ however, these snow patches may be found in Argentina below elevations of 2200 $m$ (GARLEFF 1977). The pressure and weight of the snow causes krummholz in Araucaria trees and Nothofagus that grow close to the treeline.

\subsection{Cryoplanation surfaces}

The term cryoplanation, or EAKIN (1916) altiplanation, is used to explain the combination of phenomena, which create a cryogenic environment of planation, cryoplanation or a plain surface on the summits of high mountain areas; called summit surface in this last case, or a terrace in valleys and on slopes, called cryoplanation terraces (Fig. 17). They may reach a width of $250 \mathrm{~m}$ and a length of 1 $\mathrm{km}$, with a Quaternary cover of a thickness of up to 3 m (CZUDEK 1989).

Among the most important processes are:

a) the activity of snow patches or nival phenomena,

b) cryoweathering, and

c) solifluction, reinforcing the removal of the cryosediment (DEMEK 1969).

According to Suchodrovskiy's theory (1967,1979, see CZUDEK 1989) there would be no general change caused by cryogenesis on the slope, but rather an overprint process. This makes us think of a pre-existing planation which for geological reasons increases the erosion action, while the summit surface would represent a final state in a cycle of erosive states (CZUDEK 1989).

It cannot be ruled out that a surface of a cryogenic environment has a polygenetic origin. 
Summit cryoplanation surfaces are closely related to Andean continuous permafrost. In the Andes of San Juan, Argentina ( $\left.30^{\circ} \mathrm{S}\right)$ cryoplanation surfaces were taken as indicators of continuous permafrost, with temperatures $<-4^{\circ} \mathrm{C}$, at elevations over $5000 \mathrm{~m}$ by SCHOLL (1992). In the Southern Andes they appear as low as $1590 \mathrm{~m}$ (approximately $46^{\circ} \mathrm{S}$ ) in the area of Cerro Ap Iwan (GARLEFF 1977). Cryoplanation surfaces between slopes may favour the accumulation of cryoregolithe as a cryobasin (Fig. 16), as in the cases of Mendoza, at almost $4000 \mathrm{~m}$ (TROMBOTTO et al. 1984).

\subsection{Tor (felsburg) (HAMELIN \& COOK, 1967)}

These are areas of incomplete cryoweathering closely linked with the structures of the rocks and in particular with their degree of fissility. According to the classification by FRENCH (1988) the following tors may be distinguished: 1) slope tors: located on the valley sides and surrounded by slopes with a detrital cover, with inclination angles between $20^{\circ}$ and $30^{\circ}$, depending on the type of rock and 2) apical tors. The term Chalt (in aoniken, a Patagonian native language) is used to describe a group of tors (Fig. 4) with a shape of saw-tooth surface (R. Casamiquela, pers. comm., 1993), an example of this is the Cerro Fitz Roy.

\subsection{Cryogenic slopes}

Due to the Andean periglacial morphodynamics the following are the prevailing geoforms on slopes:

- Detrital slopes (Schutthaenge) of periglacial origin (Fig. 13) are of enormous hydrological importance for the Andean oasis (TROMBOTTO 1991). These are slopes built by rocks and blocks of considerable thickness and with an important percentage of embedded fine material or cryoregolithe, displaying creep or even other attached geoforms. These slopes may contain interstitial ice or "cement ice", that cements rocks together and is of important hydrological value in the summer season. The granitic detrital slopes in the Lagunita del Plata, Mendoza, display inclination angles of predominantly $29^{\circ}$ to $34^{\circ}$, while those of the greywacke vary between $24^{\circ}$ and $31^{\circ}$.

- Richter denudation slopes are wide and gentle slopes (Fig. 17) with a relatively thin layer of cryofragmented rocks. Also glatthang (from
German Glatthang, pl. Glatthaenge). These are usually cut by the scars of snow avalanches and snow - debris avalanches and mudflows, which are characteristic of semi-arid periglacial environments in the Central Andes. GARLEFF (1977) described Glatthaenge for the Andes of San Juan, Valle de Agua Negra, above $4500 \mathrm{~m}$ and to the south. They have been reported in different parts of Mendoza, as for example in the area of the Laguna del Diamante $(>3300 \mathrm{~m})$, where STINGL \& GARLEFF (1983) mapped these slopes. They studied the cryodynamics in the region of Cuyo and part of the Northwest region (NOA) in Argentina in search of the generating factor for this kind of slopes in this semiarid mountain regions. The same authors emphasize the importance of the petrology of the Nevados of Famatina $\left(29^{\circ} \mathrm{S}\right)$, with schists and quartzites, that help to form these slopes on the periglacial level above $4000 \mathrm{~m}$.

In Chile on the border with Perú, ABELE (1982) analysed these phenomena and distinguished a type of gently inclined slope associated with the cycles of freezing and thawing of another slope in the area of neblina (a misty altitudinal level), where the effect of the growth and hydration of the salt is observed.

- Talus or talus cones (Fig. 18). Generally great accumulations of angular shaped rocks and cryoregolithe of different sizes may be observed on the sides and feet of the mountains in cryogenic environments. These are created by the dynamics of freezing, weathering and the contribution of nivodetritic avalanches and are denominated talus. They belong to the phase that FRANCOU (1982) called d'eboulisation, that is the disintegration caused by primary chutes or primary rockfalls. Many different types and combinations of this phenomenon have been classified so far, according to the changes in their genesis and according to their respective shapes: rockfall talus (for the fall and accumulation of cryofragments), alluvial talus, avalanche talus, etc. (RAPP 1959, WHITE 1981).

FRANCOU (1984) points out that in Huamparcocha, Peru $\left(12^{\circ} \mathrm{S}\right)$, above $4900 \mathrm{~m}$, the origin of the talus, apart from the exposition, is influenced by the petrographic characteristics of andesites and ryolithes. These rocks, which in that region are also affected by intrusive igneous material, are altered by tectonics and hydorthermalism (epidotisation), and seem to be 


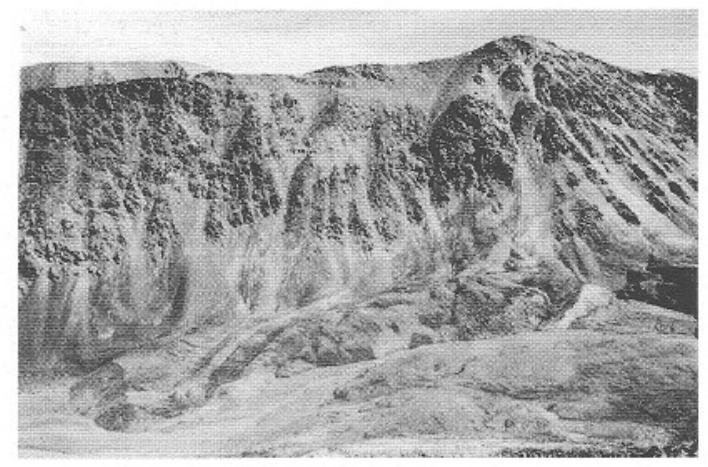

FIGURE 18 - Protalus and talus rock glacier at Strelkov glacier valley, Cerro El Plata (6310 m ASL), Cordillera Frontal, Mendoza, Argentina (March 1996).

easily attacked by cryoweathering. Similar conditions, with intrusives, tectonics and metamorphism were also determined as important factors for the genesis of periglacial forms at the Lagunita del Plata, Mendoza (TROMBOTTO 1991).

- Protalus ramparts. Protalus ramparts are particular sedimentary forms associated with snow patches in postfrontal depressions, attached to the lateral mountain slopes on which rocks slide down and accumulate at their fronts. In the Central Andes they are very well represented and are often interpreted as embryonic states of a type of rock glacier.

A transversal cut into periglacial slopes and valleys may frequently reveal grèzes litées (Fig. 19) as in the Andes of Mendoza. Their genesis needs to be studied more thoroughly. They consist of altering sedimentary layers, granulometrically different from one another. The main axes of their clasts are orientated slope downwards. TROMBOTTO (1991) presented supranival and ennival (from the upper part or from the interior of a snow patch) as possible genesis of some structures on the periglacial slopes of the Andes of Mendoza.

Debris slopes and relict grèzes litées are abundant in the Cuyo region of Argentina, below and close to the present periglacial level, but would still have to be mapped in detail.

\subsection{Rock glaciers}

Rock glaciers are cryogenic lobular or tongue-shaped mesoforms expressing the plastic deformation and creeping of mountain permafrost (see BARSCH 1969, 1977; CORTE 1976). They are certainly the most important geoforms of the

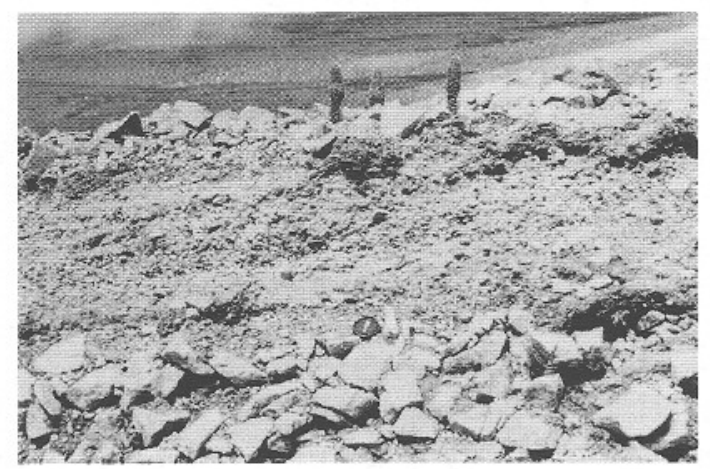

FIGURE 19 - Grèzes litées. Portillo Argentino, Eastern slope, Mendoza, Argentina, about 3800 m ASL. Diameter of the camera lid: $5.4 \mathrm{~cm}$ (March 1997).

Andes. For decades their enormous hydrological value for the Central Andes has been pointed out (CORTE 1976, BUK 1983).

Through the open system of the active layer a water storage is produced, which maintains the geocryological balance. The solid precipitation (snow) that penetrates the active layer and the freezing of the latter creates the system of water storage in high mountains areas. In the summer season the active layer is thawing and the discharge of the rivers increases. Thawing, summer snowfalls and the lowering of the permafrost table to greater depths, caused by the warming process of the last decades, establish a direct relation between the behaviour of temperatures on rock glacier surfaces and the discharge of the Andean rivers. Frozen areas, with permafrost or debriscovered ice in the Central Andes, as well as in other South American cryogenic regions constitute therefore more important water supplies than glacier regions.

In the tropical Andes rock glaciers appear from $20^{\circ} \mathrm{S}$ onwards, associated with the periglacial level located at $4500 \mathrm{~m}$ and above (FRANCOU 1984). Francou and his colleagues have been studying the rock glacier Cerro Caquella in Bolivia as indicator of climate variability (1999). In Argentina the first reference of rock glaciers would be the publication by CATALANO (1926), who called them litoglaciares and describes them for the Puna region.

The glaciers of the Central Andes often culminate in detrital or morainic tongues that actually represent debris-covered glaciers. Following the classification by BARSCH (1969) these forms were designated in general debris rock glaciers (Figs. 20 and 21) in order to distinguish them from the ones of exclusively cryogenic origin 
or the so-called talus rock glaciers (Fig. 18). CORTE (1987) later presented a very complex taxonomy including other geoforms.

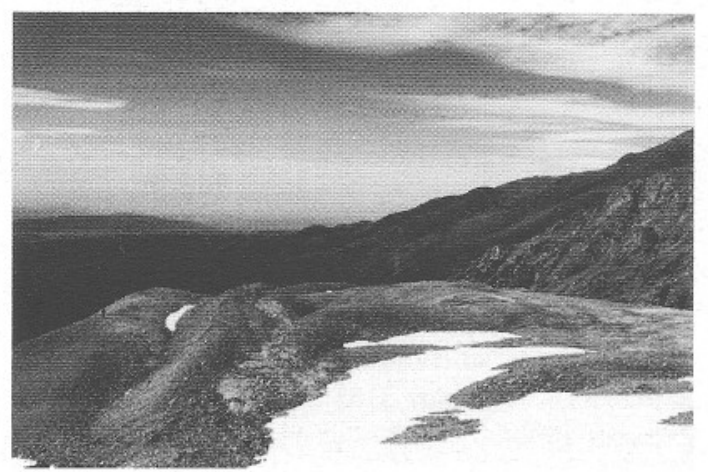

FIGURE 20 - Nose of the debris rock glacier Morenas Coloradas, Cordón del Plata, Mendoza, Argentina, ca. $3560 \mathrm{~m} \mathrm{ASL}, 32^{\circ} 58^{\prime} \mathrm{S}$ and $69^{\circ} 21^{\prime} \mathrm{W}$ (November 1999).

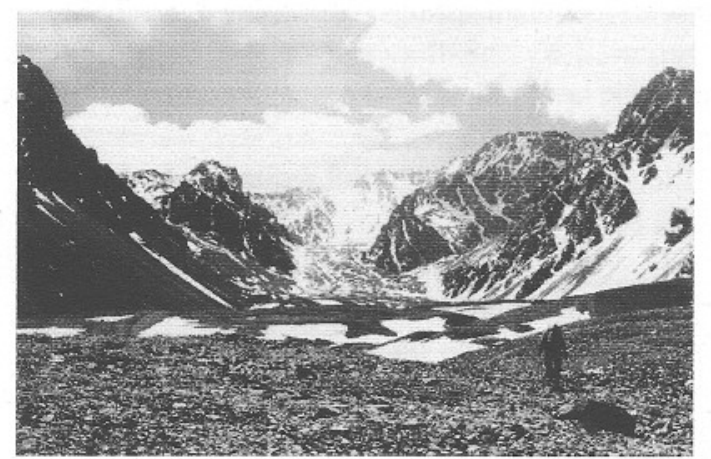

FIGURE 21 - Debris rock glacier Morenas Coloradas, Cordón del Plata, Mendoza, Argentina, 32 58' S and $69^{\circ} 21^{\prime} \mathrm{W}$ (November 1999).

The embryonic forms of talus and cryogenic slopes (Fig. 18) fed with material from nivodetritic avalanches and indications of movement were termed protalus or embryonic rock glaciers (TROMBOTTO 1991)

In the Central Andes and down to $3200 \mathrm{~m}$ the rock glaciers may have ice and be inactive, but below $3000 \mathrm{~m}$ they are considered fossil and close to this elevation they were only active during the Würm (BARSCH \& HAPPOLDT 1985).

It has to be mentioned again that the air temperature is usually in certain disharmony with the soil temperature profile, resulting from a very particular thermal balance according to the radiation, orientation, constitution of the rocks, and origin of the ice being among the most important factors.

High surface temperatures, between air and soil, as well as their evolution with depth, were registered in the periglacial level of Mendoza and
San Juan, Central Andes, Argentina. They surpass $30{ }^{\circ} \mathrm{C}$ (TROMBOTTO 1991, SCHROTT 1994). At the same time a correlation between global radiation and daily soil temperature variations was observed to depths of $1 \mathrm{~m}$ (HAPPOLDT \& SCHROTT 1989). A detailed study by SCHROTT (1994) sustains that the appearance of permafrost is mainly related to the energetic balance determined by high solar radiation $(20,6$ and $\left.22,3 \mathrm{MJ} \mathrm{m}^{-2} \mathrm{~d}^{-1}\right)$. A shadowed spot with extremely low radiation would explain atypical permafrost (e.g. at low elevations, SCHROTT 1999).

In the northern Chilean Andes, and within the region of the South American Arid Diagonal between $24^{\circ}$ and $27^{\circ} \mathrm{S}$, Swiss colleagues (KAMMER et al. 1999) mapped rock glaciers with great precision resulting in diagnostic parameters for their activity and defined their disappearance as active geoforms at a precipitation regime of $\leq 175 \mathrm{~mm}$.

Rock glaciers in the Central Andes, Argentina, show signs of activity even at MAAT of $0^{\circ} \mathrm{C}$ at elevations of $3700-3800 \mathrm{~m}$ and mean annual precipitations around $500-600 \mathrm{~mm}$.

The rock glacier El Salto for example has permafrost at an elevation of $3600 \mathrm{~m}$ (BARSCH \& KING 1989) and at Morenas Coloradas, a rock glacier of glacigenic origin, the permafrost limit reaches down to even $3400 \mathrm{~m}$. These last conditions seem to be related to the dry climate and the global energetic balance of periglacial environments in the Central Andes, factors which increase the efficiency and the radius of influence of cryogenic phenomena to lower elevations.

Dryness, the global energy balance and regional atypical phenomena coincide with what LLIBOUTRY (1986) observed for the major rock glaciers in Chile, towards $33^{\circ} \mathrm{S}$ with signs of activity down to $3500 \mathrm{~m}$ and temperatures of 1 to $2^{\circ} \mathrm{C}$.

Among the few existing measurements of rock glacier movement in-South America, there are the ones made by MARANGUNIC (1976) who calculated the rate on the margins of the rock glacier El Pedregoso, in Chile, at $3700 \mathrm{~m}$ at approximately $32^{\circ} \mathrm{S}$, to be $11 \mathrm{~cm} /$ year. This rock glacier has a surface of $0,3 \mathrm{~km}^{2}$ and a summer discharge of $4-9 \mathrm{l} / \mathrm{sec}$.

The case of the Dos Lenguas rock glacier in San Juan, Argentina, at $30^{\circ} \mathrm{S}$ is similar. It has a similar surface and a discharge of 5-8 1/sec. (SCHROTT 1994). Schrott thinks that the upper basin of Agua Negra, where the Dos Lenguas is located, with $2 \mathrm{~km}^{2}$ of rock glaciers in total, may 
cause a discharge of up to $50 \mathrm{l} / \mathrm{sec}$. On the other hand the Morenas Coloradas basin with permafrost and rock glaciers generates the discharge of the Vallecitos river with $505 \mathrm{l} / \mathrm{sec}$., which is of vital importance to water supply of Mendoza.

This study of periglacial hydrology is of strategic importance for the near future.

\subsection{Asymmetrical valleys}

Another typical characteristic of periglacial environments are the asymmetrical valleys. In the Southern Hemisphere north-facing periglacial slopes are warmer and less steep with a major frequency of freezing and thawing cycles and more solifluction than the south-facing slopes. The south-facing slopes are colder, steeper and have rougher surfaces.

Periglacial saucer-shaped valleys, dells, many of which are asymmetrical, are characteristic geoforms of an Andean periglacial environment. They may also be identified by their covering with solifluction sediments (see SEMMEL 1985).

GARLEFF et al. (1989) made a detailed inventory of fossil dells for the geomorphological map: La Junta-Agua Nueva, where they interpreted morphodynamic and paleoclimatic changes in the area bordering the Andes ( $\left.35^{\circ} \mathrm{S}\right)$.

\section{PERIGLACIAL PRESENCE ON THE PEATLANDS}

Many of the Andean peatlands of southern South America represent the environment of a moor or anmoor, depending on their content of organic material. In the Central Andes the peatlands usually have a genesis similar to that of a minerotrophic fen.

The inhabitants of such peatland environments (Fig. 22) in certain Andean subtropical regions and Patagonian call their habitat mallín or vega (anmoors). These mallines (plural) are also designated as humid or swampy prairies (BOELCKE 1957). They frequently border the basalt plateaus of Patagonia. These mallines or moors are of great importance in Geocryology as far as their present seasonal freezing is concerned and because many of these environments are remnant ecosystems that were created as the Pleistocene ice retreated. They are also old areas associated with paleopermafrost e.g. with a paleoperiglacial environment.

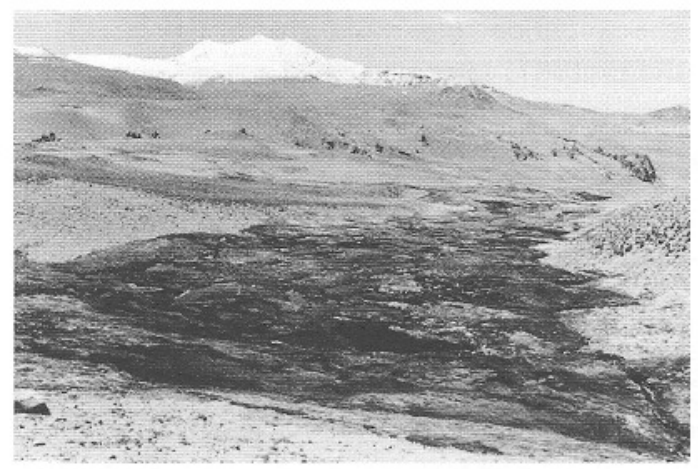

FIGURE 22 - Mallín, Turbera del Yaucha, Central Andes, Mendoza, Argentina $3155 \mathrm{~m} \mathrm{ASL}$, ca. $34^{\circ} 10^{\prime} \mathrm{S}$ (December 1996).

An environment of the fen - or minerotrophic peatland type - is produced by the existence of an aquatic environment, for example close to mountain springs, streamlets or riverbeds originated by the thawing of the altitudinal cryogenic level soil, when the water has difficulties to percolate or to drain as it encounters impermeable sedimentary beds (e.g. glacial sediments, volcanic ashes etc.).

Geomorphologically speaking, two main types of anmoors or mallines are found: one in the valleys and one on mountain slopes. They occur at the level that AMBROSETTI et al. (1986) called altoandean level, or Andean tundra (see TROMBOTTO 1991).

These environments favour the growth of diverse vegetation, saturated with water and accumulated vertically, as the layers are not completely degraded, thus creating peatlands or very important organic soils in this way. The cold temperatures have an essential role in slowing down decomposition processes of the organic material. Seasonal cryogenesis acts as a generator of thufurlike seasonal freezing forms, in the environments of the Central Andes as well as in the environments of the Argentine-Chilean South (e.g. continental peatlands with the genus Carex and Caltha, ROIG et al. 1985). Thufurs (Fig. 23), which often appear in association with the periglacial phenomena, have been widely ignored by researchers.

In the area of Última Esperanza in the Magellan region in the south of Chile and in Tierra del Fuego and the Andean woods in Argentina, the moors however, are closely linked with high precipitations and with characteristics corresponding to ombrotrophic moors. ROIVAINEN (1954) 


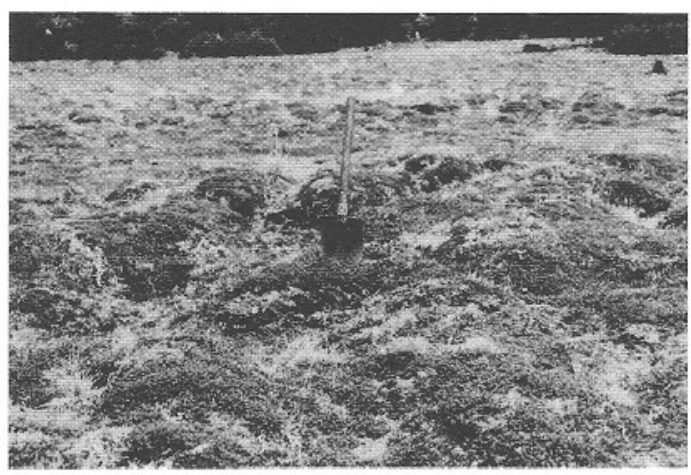

FIGURE 23 - Thúfur, San Lorenzo Este glacier, Río Lácteo valley, Southern Andes, Santa Cruz, Argentina, ca. $1000 \mathrm{~m} \mathrm{ASL}$, ca. $47^{\circ} 37^{\prime} \mathrm{S}$ and $72^{\circ} 12^{\prime} \mathrm{W}$. Length of the spade: $65 \mathrm{~cm}$, (December 1999).

made an important classification of moors in Tierra del Fuego. The characteristic moor with Sphagnum magellanicum (white moor) of Tierra del Fuego is just one example.

In the context of the works on the "Botanical Transect of Southern Patagonia" (BOELKE et al. 1985) Roig added an ecological component to the environmental concept of the peatlands in southern South America by incorporating them into the so-called tundra ecosystem. ROIG (1984) reported permafrost at an elevation of $900 \mathrm{~m}$ and at a depth $30-40 \mathrm{~cm}$ and poorly developed polygonal soil structures on the tundra called xeric Andean tundra.

\section{FORMS OF DEGRADATION IN CRYOGENIC ENVIRONMENTS}

\section{CORTE (1980, 1997) analysed} thermokarsts (Fig. 24) or cavities caused by subsidence or thawing. Here the ice began to disappear and the isotherm of $0^{\circ} \mathrm{C}$ raised, or facies of thermokarst, in debris rock glaciers in Mendoza. A degradation phase was suggested by FRANCOU et al. (1999) for the tropical rock glacier Caquella in Bolivia based on low apparent resistivity in the geoelectric soundings.

This topic is almost unexplored in South America. According to TROMBOTTO et al. (1997, 1999; compare BARSCH \& KING 1989) not only has the active layer deepened in the last 20 years, but also the isotherm of $0^{\circ} \mathrm{C}$ ascended altitudinally up to $3860 \mathrm{~m}$ at $33^{\circ} \mathrm{S}$ in the last decade. A thermokarst area of the rock glacier Morenas Coloradas, Mendoza (at 4000 - 4100 m) does not reveal any visible permafrost occurrence but does reveal the original forms that today

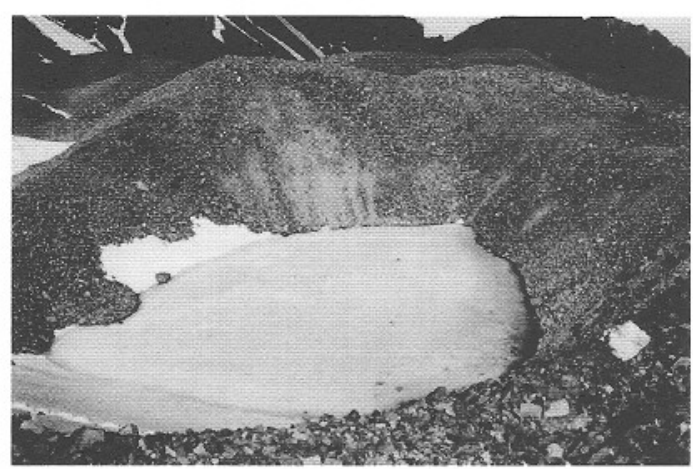

FIGURE 24 - Thermokarst, Morenas Coloradas rock glacier, Cordón del Plata, Mendoza, Argentina, 4100 m ASL (November 1999).

appear dry or with lakes which freeze or thaw according to meteorological annual variations.

Another phenomenon revealing permafrost degradation is the occurrence of mudflows, which represent sudden movements of soil, a form of natural disasters.

\section{PAST CRYOGENIC ENVIRONMENT AND PALEOPERMAFROST}

Outstanding fossil cryogenic structures in southern South America during the Last Glacial (LG) and according to various authors may be observed on the accompanying map (Fig. 25). The influence of the periglacial environment during the Pleistocene seems to have reached even into Brazil, participating in the evolution of slopes and leaving behind relict talus, signs of solifluction and freezing. No signs of permafrost are observed, as at the plateau of Itiatiaia $\left(22^{\circ} \mathrm{S}\right)$, a region with mountains over $2700 \mathrm{~m}$ (MODENESI 1992, MODENESI-GAUTTIERI \& TOLEDO 1996, MODENESI-GAUTTIERI \& NUNES 1998).

KEIDEL (1922) described debris slopes and summit peniplains in the Puna region (Argentina) and made first assumptions about cold episodes in the past. CZAJKA (1955), later stated that the rock glaciers reached down to approximately $2600 \mathrm{~m}$ in the Nevados del Aconquija (NW Argentina) at approximately $27^{\circ} \mathrm{S}$ and $66^{\circ} \mathrm{W}$. The same author (1957) also reported fossil rock glaciers in the Sierra de la Ventana (Province of Buenos Aires), at $38^{\circ} \mathrm{S}$ and $62^{\circ} \mathrm{W}$ and made one of the first paleoclimatic deductions about cryogenic forms and phenomena in Patagonia. $\mathrm{He}$ considered a sequence of climatic denudation cycles, with tundra - loess phase during the 
Pleniglacial for example, when enormous networks of Patagonian ice wedges were created. GARLEFF \& STINGL (1986) believe that the approximately continuous permafrost level descended down to $2500 \mathrm{~m}$ in the Southern Central
Andes - Lake Region - North Patagonia (Argentina) and to $1000 \mathrm{~m}$ in the Northwest Argentina. The authors consider a difference of the MAAT between the present and the $\mathrm{LG}$ of $15^{\circ} \mathrm{C}$ in the first case, and until $9^{\circ} \mathrm{C}$ and together with less

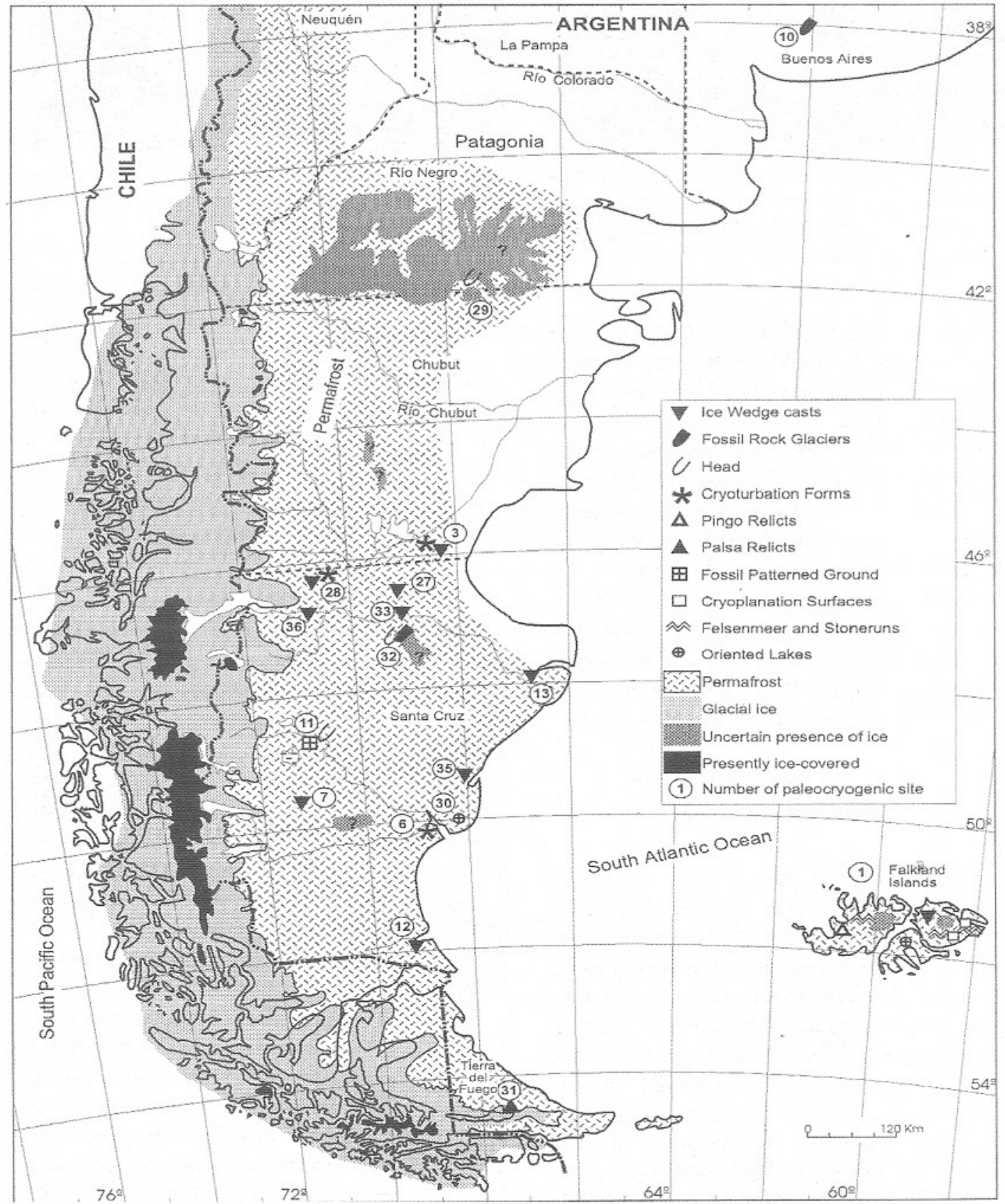

FIGURE 25 - Finiglacial in Patagonia with registered cryogenic structures and forms assigned to the Last Glaciation Maximum (20 ka) according to different authors.

Paleocryogenic sites on the map: (1) Malvinas, Falkland Islands; (3) Pampa del Castillo, Holdich; (6) Río Santa Cruz; (7) Tres Lagos, Río Chalía; (10) Sierra de la Ventana; (11) Lago Cardiel; (12) Chimen Aike, Río Gallegos; (13) Río Deseado; (27) Las Heras (North); (28) Cerro Kensel; (30) Río Santa Cruz and Río Deseado; (31) Lago Cami; (32) Meseta El Pedrero, Region of the Meseta de las Lagunas Sin Fondo; (33) Romberg; (35) Puerto San Julián; (36) Telken. 
than $50 \%$ of today's precipitation in the second case. These conditions must have considerably affected and stopped the cryogenic activity in the South American Arid Diagonal.

The Patagonian epigenetic ice wedge casts were mentioned by AUER (1956, 1970), CZAJKA $(1955,1957)$ and CORTE (1967, 1997). Syngenetic ice wedge casts were recently mentioned by TROMBOTTO (1996). Based on the epigenetic and syngenetic ice wedge casts the extent of permafrost during the Pleistocene Age up to the rivers Río Negro and Río Colorado could be estimated. The difference of the MAAT between present temperatures and those during the $\mathrm{LG}$ is about $14^{\circ} \mathrm{C}$ for South Patagonia (TROMBOTTO 1994).

The Falkland Islands express the characteristics of the past periglacial maritime climate. On the Falkland Islands ANDERSSON (1906) was one of the first scientists to mention solifluction, introducing the term internationally. Fossil periglacial geomorphology of the maritime type was analysed by CLARK (1972). The islands offer a great variety of cryogenic fossil forms: cryoplanation surfaces, tors, nivation hollows, ice wedge casts, felsenmeer and the famous stoneruns or blockstroeme.

Recently various authors (CORTE 1991; TROMBOTTO 1994, 1998; TROMBOTTO \& AHUMADA 1995) classified paleogeocryology under climato-stratigraphical criteria. CLAPPERTON (1993) and TROMBOTTO (1996) give abundant bibliographical references on this topic for South America, particularly since 1980 for Argentina.

\section{ACKNOWLEDGEMENTS}

I would like to thank Sabine Herfert for the translation of the manuscript, Dr. Jerry Brown for his comments and the improvement of the English, and Daniel Dueñas for his collaboration with the maps.

\section{REFERENCES}

ABELE, G. 1982. Geomorphologische und hygrische Höhenzonierung des Andenwestabfalls im peruanischchilenischen Grenzgebiet. Erdkunde 82 (4): 266-278.

AHUMADA, A.-L. 1987. Procesos Criogénicos y Mineralógicos. Universidad Nacional de
Tucumán. Doctor thesis (unpublished), 208 pp.

- 1992. Periglacial Climatic Conditions and Vertical Form Associations in Quebrada Benjamín Matienzo, Mendoza, Argentina. Permafrost and Periglacial Processes 3 (3) : 221 - 224 .

AMBROSETTI, J.; DEL VITO, L. ; ROIG, F. 1986. La vegetación del Paso de Uspallata, Provincia de Mendoza, Argentina. Geobotanisches Institut ETH, Stiftung Rübel, 91: 141-180.

ANDERSSON, J. 1906. Solifluction a component of subaerial denudation. Journal of Geology, 14: 91-112.

ANGELINI, U. 1990. Diseño estructural de caminos sometidos a la acción del congelamiento. Regionalización del Método. Dirección de Ingeniería Vial, Ministerio de Economía, Chubut, 56 pp.

AUER, V. 1956. The Pleistocene of Fuego-Patagonia. Part I: The Ice and Interglacial Ages. Annales Academiae Scientiarum Fennicae 3(45): 226.

— 1970. The Pleistocene of Fuego-Patagonia. Part V: Quaternary Problems of Southern South America. Annales Academiae Scientiarum Fennicae 3(100): 194.

BARANOV, I.YA. 1964. Principles of Geocryology. National Research Council of Canada, Technical Translation 1121: 85 pp.

BARSCH, D. 1969. Studien und Messungen an Blockgletschern in Macun, Unterengadin. Zeitschrift für Geomorphologie (Suppl.) 8: 11-30.

— 1977. Alpiner Permafrost - ein Beitrag zur Verbreitung, zum Charakter und zu Ökologie am Beispiel der Schweizer Alpen. In: H. POSER (Hrsg.) Formen, Formengesellschaften und Untergrenzen in den heutigen periglazialen Höhenstufen der Hochgebirge Europas und Afrikas zwischen Arktis und Äquator. Göttingen, p.118-141.

—; HAPPOLDT, H. 1985. Blockgletscherung und holozäne Höhenstufengliederung in den mendozinischen Anden, Argentinien. Zentralblattes für Geologie und Paläontologie. 1(11/12): 1625-1632.

-; KING, L. 1989. Origin and geoelectrical 
resistivity of rockglaciers in semi-arid subtropical mountains (Andes de Mendoza, Argentina). Zeitschrift für Geomorphologie. N.F. 33 (2): 151-163.

BIGARELLA, J.; MOUSINHO, M. ; XAVIER DA SILVA, J. 1969. Processes and Environments of the Brazilian Quaternary. In: T.L. Péwé (Edit.)The Periglacial Environment, McGill-Queen's University Press, Montreal, p. 417 - 487.

BOELCKE, O. 1957. Comunidades herbáceas del norte de la Patagonia y sus relaciones con la ganadería. Revista de Investigaciones Agrícolas 11 (1): 5-98.

_; MOORE, D. M. ; ROIG, F.A. (Edit.). 1985. Transecta Botánica de la Patagonia Austral. Instituto Salesiano de Artes Gráficas, Buenos Aires, 733 pp.

BUK, E. 1983. Glaciares de Escombros y su Significación Hidrológica. Acta Geocriogénica 1: 22-38

— 1992. Índice y frecuencia de congelamiento en Patagonia y región cordillerana pedemontana. Workshop Nacional "Geocriología y Paleoclima Nordpatagónico", Puerto Madryn, 8 pp.

CATAlanO, L. 1926. Contribución al conocimiento de los fenómenos geofísicos atmosféricos. Buenos Aires: Dirección General de Minas, Geología e Hidrología,, 78 pp. (Publicación 24).

CLAPPERTON, C. 1993. Quaternary Geology and Geomorphology of South America. Elsevier, Amsterdam, 779 pp.

CLARK, R. 1972. Periglacial Landforms and Landscapes in the Falkland Islands. Biuletyn Peryglacjalny 21: 33 - 50.

CORTE, A. 1953. Contribución a la Morfología Periglacial de la Alta Cordillera con Especial Mención del Aspecto Criopedológico. Anales del Departamento de Investigaciones Científicas, 1(2): 54pp.

— $1962 \mathrm{a}$. The frost behaviour of soils I: Vertical sorting. Highway Research Board, Bulletin 317: 9-34

_ 1962 b. The frost behaviour of soils II: Horizontal sorting. Highway Research Board, Bulletin 331: 46-66.

- 1967. Informe preliminar del progreso efectuado en el estudio de las estructuras de crioturbación pleistocénicas fósiles en la provincia de Santa Cruz. Terceras Jornadas Geológicas Argentinas, p. 9 - 19.

- 1976. Rock Glaciers. Biuletyn Peryglacjalny 26: 175-197.

- 1980. Glaciers and glaciolithic systems of the Central Andes. World Glacier Inventory, Proceedings of the Riederalp Workshop, IAHS-AISH Publ. 126: 11-24.

--- 1983. Los conceptos: geocriogénico parageocriogénico y glacial - paraglacial en los Andes Centrales de Argentina, latitud $30^{\circ}$. Acta Geocriogénica 1: 48-61.

— 1987. Rock glacier taxonomy. In: J. Giardino, J. Shroder Jr. \& J. Vitek (Edits.): Rock Glaciers. Allen and Unwin, Winchester, p. 27-39.

1991. Chronostratigraphic Correlations of Cryogenic and Glacigenic Episodes in Central Andes and Patagonia. Permafrost and Periglacial Processes 2 (1): 67 - 70.

1997. Geocriología. El Frío en la Tierra. Ediciones Culturales de Mendoza, Fundar Editorial Gráfica, 398 pp.

CZAJKA, W. 1955. Rezente und pleistozäne Verbreitung und Typen des periglazialen Denudationszyklus in Argentinien. Acta Geographica 14, 10: 121 - 140.

1957. Die Reichweite der pleistozänen Vereisung Patagoniens. Geologische -----

CZUDEK, T. 1989. Kryoplanationsterrassen im rezenten Dauerfrostboden. Acta Scientiarum Naturalium Academiae Scientiarum Bohemoslovacae Brno, Nova Series 23(8): 41 pp.

DEMEK, J. 1969. Cryogene Processes and the Development of Cryoplanation Terraces. Biuletyn Peryglacjalny 18: 115-125.

DYKE, A. ; ZOLTAI, S. C. 1980. RadiocarbonDated Mudboils, central Canadian Arctic. Scientific and Technical Notes in Current Research, Part B, Geological Survey of Canada, Paper 80-1B: 271 - 275.

EAKIN, H. 1916. The Yukon-Koyuruk region Alaska. U.S.Geological Survey Bulletin, 631 p.

FRANCOU, B. 1982. Chutes de pierres et éboulisation dans les parois de l'étage périglaciaire. Revue de Géographie Alpine 70 (3): 279-300.

1984. Données préliminaires pour l'étude des 
processus périglaciaires dans les hautes Andes du Pérou. Geomorphologie Dynamique 33e (4): 113-126.

-; FABRE, D.; POUYAUD, B.; JOMELLI, V. ; ARNAUD, Y. 1999. Symptoms of Degradation in a Tropical Rock Glacier (Bolivian Andes). Permafrost and Periglacial Processes 10 (1): 91 - 100.

FRENCH, H.M. 1988. The Periglacial Environment. Longman, London, 309 pp.

GARLEFF, K. 1977. Höhenstufen der argentinischen Anden in Cuyo, Patagonien und Feuerland. Göttinger Geographische Abhandlungen (68): 150 pp.

-_; STINGL, H. 1986. Geomorphologische Aspekte aktuellen und vorzeitlichen Permafrostes in Argentinien. Zentralblattes für Geologie und Paläontologie 1(9/10): 1367-1374.

---; ABRAHAM DE VAZQUEZ, E-M. ; WAHLE, E, H. 1989. Geomorphologische Karte 1:100.000, La Junta-Agua Nueva, Provinz Mendoza/Argentinien. Bamberger Geographische Schriften (7): 100 pp.

GONZÁLEZ BONORINO, F. ; TERUGGI, M. 1952. Léxico Sedimentológico. Buenos Aires: Museo Argentino de Ciencias Naturales Bernardino Rivadavia, 164 pp. (Publicación 6).

GORBUNOV, A. P. 1978. Permafrost investigation in high-mountain regions. Arctic and Alpine Research 10 (2): 283-294.

— 1993. Origin of Permafrost Lake Deposits in the Central Andes. Permafrost and Periglacial Processes 4 (4): 335 - 338.

GRAF, K. 1971. Beiträge zur Solifluktion in den Bündner Alpen (Schweiz) und in den Anden Perus und Boliviens, Juris Druck Verlag, Zürich, 153 pp.

GROEBER, P. 1936. Oscilaciones del clima en la Argentina desde el Plioceno. Revista del centro de Estudiantes del Doctorado de Ciencias Naturales 1 (2): 71-84.

HAEBERLI, W.; GUODONG, C., GORBUNOV, A. ; HARRIS, S. 1993. Mountain Permafrost and Climatic Change. Permafrost and Periglacial Processes 4 (2): 165 - 174.

HALL, K. 1998. Nivation or Cryoplanation: Is there any difference? In: INTERNATIONAL CONFERENCE ON PERMAFROST, 7 , Yellowknife, Program, Abstracts and IPA
Reports, p. 149 - 150.

HAMELIN, L. ; COOK, F. 1967. Illustrated Glossary of Periglacial Phenomena. Les Presses de l'Université Laval, Quebec, 237 pp.

HAPPOLDT, H. ; SCHROTT, L. 1989. Globalstrahlung und Bodentemperaturen in der periglazialen Höhenstufe am Aconcagua, argentinische Hochanden. Bayreuther Geowissenschaftliche Arbeiten 14: $35-45$.

HASTENRATH, S. 1971. Beobachtungen zur klima-morphologischen Höhenstufung der Cordillera Real (Bolivien). Erdkunde 25(2): 102-108.

HEINE, K. 1994. Eis am Äquator, Wasser in der Wüste. Blick in die Wissenschaft 4(3): 46-61.

HOFFMANN, J. 1975. Atlas Climático de América del Sur. WMO, UNESCO, Cartographia, Budapest.

HÖGBOM, B. 1914. Über die geologische Bedeutung des Frostes. Bulletin of the Geology Institution of the University of Upsala 12: 257-389.

HURLBERT, S. ; CHANG, C. 1984. Ancient Ice Islands in Salt Lakes of the Central Andes. Science 224: 299-302.

- ; - 1988. The distribution, structure, and composition of freshwater ice deposits in Bolivian salt lakes. Hydrobiologia 158: $271-299$

HUMLUM, O. ; CHRISTIANSEN, H. 1998. Mountain Climate and Periglacial Phenomena in the Faeroe Islands. Permafrost and Periglacial Processes 9: 189-211.

IGARZÁBAL, A. 1983. Aspectos Geocriogénicos de Puna y Cordillera Oriental. Acta Geocriogénica 1: 133-140.

IRIONDO, M. ; KRÖHLING, D. 1995. El Sistema Eólico Pampeano. Comunicaciones del Museo Provincial de Ciencias Naturales Florentino Ameghino 5 (1): 5-48.

KEIDEL, J. 1922. Sobre la influencia de los cambios climatéricos cuaternarios en el relieve de la región seca de los Andes centrales y septentrionales de la Argentina. Boletín de la Dirección General de Minas, Geología e Hidrología, 3 - 19 p., (Publicación 5).

LAUER, W. 1979. La posición de los páramos en 
la estructura del paisaje de los Andes Tropicales. In: M.L. Salgado-Labouriau (Edit.) El Medio Ambiente Páramo, Centro de Estudios Avanzados, Editorial Arte, Caracas, p. 29-43.

LLIBOUTRY, L. 1986. Rock glaciers in the dry Andes. Data of Glaciological Studies, Moscow, p. 139-144 (Publication 58).

MARANGUNIC, C. 1976. El Glaciar de Roca El Pedregoso, Río Colorado, V Región. In: CONGRESO GEOLÓGICO CHILENO, 1, Santiago, Actas: D71-D80.

MODENESI, M. 1992. Depósitos de Vertente e Evolução Quaternária do Planalto do Itatiaia. Revista do Instituto Geológico 13 (1): 31 - 46.

MODENESI-GAUTTIERI, M.C. ; MOTTA DE TOLEDO, M.C. 1996. Weathering and the formation of hillslope deposits in the tropical highlands of Itatiaia - southeastern Brazil. Catena 27: 81 - 103.

--; NUNES, M.C. 1998. Processos Geocriogênicos Quaternários nas Cimeiras da Mantiqueira, com considerações climáticas. Revista do Instituto Geológico 19 (1/ 2): 19 - 30 .

NAUK AKADEMIJA. 1960. Fundamental concepts and terms in geocryology. Permafrost studies, Corps of Engineers, U.S.Army, Translation 28.

PÉREZ, F. 1984. Striated soil in an Andean paramo of Venezuela: its origin and orientation. Arctic and Alpine Research 16 (3): 277 289.

- 1992. 6. Miniature Sorted Stripes in the Páramo de Piedras Blancas (Venezuelan Andes). In: J. Dixon \& A. Abrahams (Edits.) Periglacial Geomorphology, John Wiley and Sons, p. 125-157.

RAPP, A. 1959. Avalanche Boulder Tongues in Lappland. Geografiska Annaler 41: 34 48.

ROIG, F. A. 1984. La Tundra Argentino-Chilena entre los paralelos $51^{\circ}$ y $56^{\circ}$ de latitud sur. Acta Geocriogénica 2: 174-196.

— 1986. Tundra y tundrización en el SW de Santa Cruz, Argentina. Acta Geocriogénica 4: 129-140.

—; ANCHORENA, J.; DOLLENZ, O.; FAGGI, A.M. ; MÉNDEZ, E. 1985. Las Comuni- dades Vegetales de la Transecta Botánica de la Patagonia Austral. Primera Parte. La Vegetación del Area Continental. In: O. Boelcke.; D.M. Moore; F.A. Roig (Edits.) Transecta Botánica de la Patagonia Austral. Instituto Salesiano de Artes Gráficas, Buenos Aires, p. 350-519.

ROIVAINEN, H.; 1954. Studien über die Moore Feuerlands. Annales Botanici Societatis Zoologicae Botanicae "Vanamo" 28 (2), 205 pp.

ROMANOSVSKIY, N.; TJURIN, A.; SERGEEV, D.; AFONSKAIA, L.;BOIJKOV, S.; VOLKOVA, V.; VOLCHENḰOV, S.; ZAIJTZEV, V.; KLIMOV, I.; LISITZINA, O.; SOLOVEV, V. ; JAVELOV, A. 1989. Kurums de Golzi en el cinturón montañés. (Traducido del ruso). Academia de Ciencias, Sección Siberiana, Novosibirsk: $152 \mathrm{pp}$.

SCHOLL, K.H. 1992. Geomorphologische Kartierung im Einzugsgebiet des oberen Agua Negra, cuyanische Hochkordillere, Argentinien. Trabajo Final, 81 pp., Universität Heidelberg (unpublished).

SCHROTT, L. 1994. Die Solarstrahlung als steuernder Faktor im Geosystem der subtropischen semiariden Hochanden (Agua Negra, San Juan, Argentinien). Heidelberger Geographischen Arbeiten, (94): 199 pp.

1999. Typische und atypische Permafrostvorkommen - Klimatische Bedingungen, geomorphologische Indikatoren und Prospektionmethoden. In B.M.Möseler; R. Molenda (Hrsg.), Lebensraum Blockhalde, p. 13 -26.

SCHUBERT, C. 1979. La zona del Páramo: Morfología glacial y periglacial de los Andes de Venezuela. In: El Medio Ambiente Páramo, M.L. Salgado - Labouriau (Edit.), Centro de Estudios Avanzados, Editorial Arte, Caracas, p. 11-23.

SEMMEL, A. 1985. Periglazialmorphologie. Erträge der Forschung. Darmstadt, Wissenschaftliche Buchgesellschaft Darmstadt, 116 pp.

STINGL, H. ; GARLEFF, K. 1983. Beobachtungen zur Hang- und Wandentwicklung in der Periglazialstufe der subtropisch-semiariden Hochanden 
Argentiniens. In: Poser U. Schunke (Hrsg), Mesoformen des Reliefs im heutigen Periglazialraum, Abhandlungen der Akademie der Wissenschaften in Göttingen, Dritte Folge, 35: 119-213.

TERUGGI, M. 1957. The Nature and Origin of Argentine Loess. Journal of Sedimentary Petrology 27 (3): 322-332.

TROLL, C. 1944. Strukturböden, Solifluktion und Frostklimate der Erde. Geologische Rundschau 34: 545-694.

TROMBOTTO, D. 1988. Geocryogenic Geomorphology, East Flank of the Andes Mendoza, at $33^{\circ} \mathrm{S}$. INTERNATIONAL CONFERENCE ON PERMAFROST, 5, Trondheim, Proceedings 1: 263-267.

- 1991. Untersuchungen zum periglazialen Formenschatz und zu periglazialen Sedimenten in der Lagunita del Plata, Mendoza, Argentinien. Heidelberger Geographische Arbeiten (90): 171 pp.

1994. El Permafrost Patagónico Pasado. Revista del Museo de Historia Natural de San Rafael 12 (4): 229-249.

- 1996. The Old Cryogenic Structures of Northern Patagonia: The Cryomere Penfordd. Zeitschrift für Geomorphologie N.F. 40 (3): 385-399

— 1998. Palaeo-Permafrost in Patagonia. Bamberger Geographische Schriften, 15: $133-148$.

— ; LENZANO, L. ; BRUCE, R. 1984. Estudios periglaciales (geocriogénicos) en la Lagunita del Plata. Acta Geocriogénica 2: $232-245$.

AHUMADA A.L. 1995. Análisis de estructuras sedimentarias en los "Rodados Patagónicos" causadas por la presencia del permafrost en el criómero Penfordd, Puerto Madryn, Nordpatagonia. Revista Chilena de Historia Natural 68: 79 - 91.

BUK., E. ; HERNÁNDEZ, J. 1997. Monitoring of Mountain Permafrost in the
Central Andes, Argentina. Permafrost and Periglacial Processes 8: 123 -129.

1999. Rock glaciers in the Southern Central Andes (app. $33^{\circ}$ S.L.). Mendoza, Argentina: a review. Bamberger Geographische Schriften 19:145-173.

— ; — ; CORVALÁN, J. ; HERNÁNDEZ, J. 1998. Present state of measurements of cryogenic processes in the Lagunita del Plata, Mendoza, Argentina. Yellowknife, INTERNATIONAL CONFERENCE ON PERMAFROST, 7, Program, Abstracts and IPA Reports, p. 200-201.

—; - ; REGAIRAZ, M.C. 2000. Preliminary studies of a loess from Middle Pleistocene in the piedemont of Mendoza-Argentina at $33^{\circ} \mathrm{S}$. In: IUGS, INTERNATIONAL GEOLOGICAL CONGRESS, 31, Rio de Janeiro, Abstracts Volume [CD - ROM].

VAN EVERDINGEN, R. O. (Edit.). 1998. MultiLanguage Glossary of Permafrost and Related Ground-Ice terms. University Printing Services of The University of Calgary.

VOGT, T. ; CORTE, A. 1996. Secondary precipitates in Pleistocene and present cryogenic environments (Mendoza Precordillera, Argentina, Transbaikalia, Siberia and Seymour Island, Antarctica). Sedimentology 43: 53-64.

WASHBURN, A.L. 1970. An Approach to a Genetic Classification of Patterned Ground. Acta Geographica Lodzienšia 24: 437 - 446.

— 1979. Geocryology. E. Arnold, London, 406 pp.

WEISE, O. 1983. Das Periglazial. Gebrüder Borntraeger, Berlin - Stuttgart, 199 pp.

WHITE, S. 1981. Alpine mass movement forms (noncatastrophic): classification, description, and significance. Arctic and Alpine Research 13 (2): 127-137.

Author's address:

Dario Trombotto - Instituto Argentino de Nivología, Glaciología y Ciencias Ambientales (IANIGLA - CONICET), Bajada del Cerro s/n, CC 330, 5500 Mendoza, Argentina. E-mail: dtrombot@lab.cricyt.edu.ar 